\title{
A RECONSTRUCTION OF THE ENVIRONMENT OF RETTIG IN THE CITY OF TURKU, FINLAND ON THE BASIS OF DIATOM, POLLEN, PLANT MACROFOSSIL AND PHYTOLITH ANALYSES
}

\author{
VUORELA, I., GRÖNLUND, T. \& LEMPIÄINEN, T.
}

VUORELA, I., GRÖNLUND, T. \& LEMPIÄINEN, T., 1996: A reconstruction of the environment of Rettig in the city of Turku, Finland on the basis of diatom, pollen, plant macrofossil and phytolith analyses. Bull. Geol. Soc. Finland 68, Part 2, 46-71.

Palynological and palaeobotanical results from three representative cores investigated in 1994-1995 in connection with the archaeological excavations in the Rettig "Palace", Turku, Finland, are discussed. The cultural layer consisted of a heterogeneous urban upper stratum and a more humid and more homogeneous lower stratum, all resting on a clay sequence several metres thick. A chronological series of marine clay, partly river-washed and redeposited clay, and clayey soil characterized by aerophilous diatoms was determined.

Diatom analysis was used to reconstruct sedimentation environment and the development of the natural landscape in relation to land uplift. Pollen analysis was used to trace the transformation of the natural landscape into a cultural landscape and finally into an urban settlement area. The pollen results were complemented by those on plant macrofossils, which consisted of the remnants of 124 species of many different groups, such as natural, cultivated, imported, medical and collected plants. Phytoliths were investigated from the surface material of a grindstone found on the site, and typical morphotypes were described although no typical cereal phytoliths could be identified.

Key words: palaeoecology, archaeological sites, urban environment, pollen analysis, diatom flora, plants, macrofossils, phytoliths, human activity, Medieval, Turku, Finland.

Vuorela, I., Geological Survey of Finland, FIN-02150 Espoo, Finland Grönlund, T. Geological Survey of Finland, FIN-02150 Espoo, Finland Lempiäinen, T., Dept. of Biology, University of Turku, FIN-20014 Turku, Finland 


\section{INTRODUCTION}

The aim was to reconstruct the emergence of Turku area and local vegetational changes since medieval times and to investigate the history of the area from a natural landscape to the presentday urban landscape. As well as by climate and human activity, the landscape around the estuary of the River Aura has been dramatically influenced by shore displacement, the current rate of which is c. $5 \mathrm{~mm} \mathrm{yr}^{-1}$. This development was investigated by means of diatom analysis by Grönlund (T.G.), whilst the vegetational changes were reconstructed by means of pollen analysis by Vuorela (I.V.) and plant macrofossil analysis by Lempiäinen (T.L.). In addition, the surface material of a grindstone found during the excavations was studied by means of phytolith analy- sis by Vuorela. All the results from diatom analysis on three cores, pollen analysis on seven cores and plant macrofossil analysis on six soil profiles inside the excavation area (Fig. 2) were reported in detail by Vuorela et al. 1996.

Since the flora in all cores studyed has similar information, in this paper, one representative core will be presented for each method. The diatom data on the most extensice Core A (site VII/50 in Vuorela et al. 1996) are described. Core B (site IV/41 in Vuorela et al. 1996) was studied for pollen records. Even though the interpretation of plant macrofossils is based on all six cores analysed, the emphasis is on Core C (site $\mathrm{I} / 2$ in Vuorela et al. 1996; Fig. 2). Since the pollen and macrofossil taxa were very similar in all the cores investigated, a list comparing and summarizing the pollen and macrofossil taxa is also given.

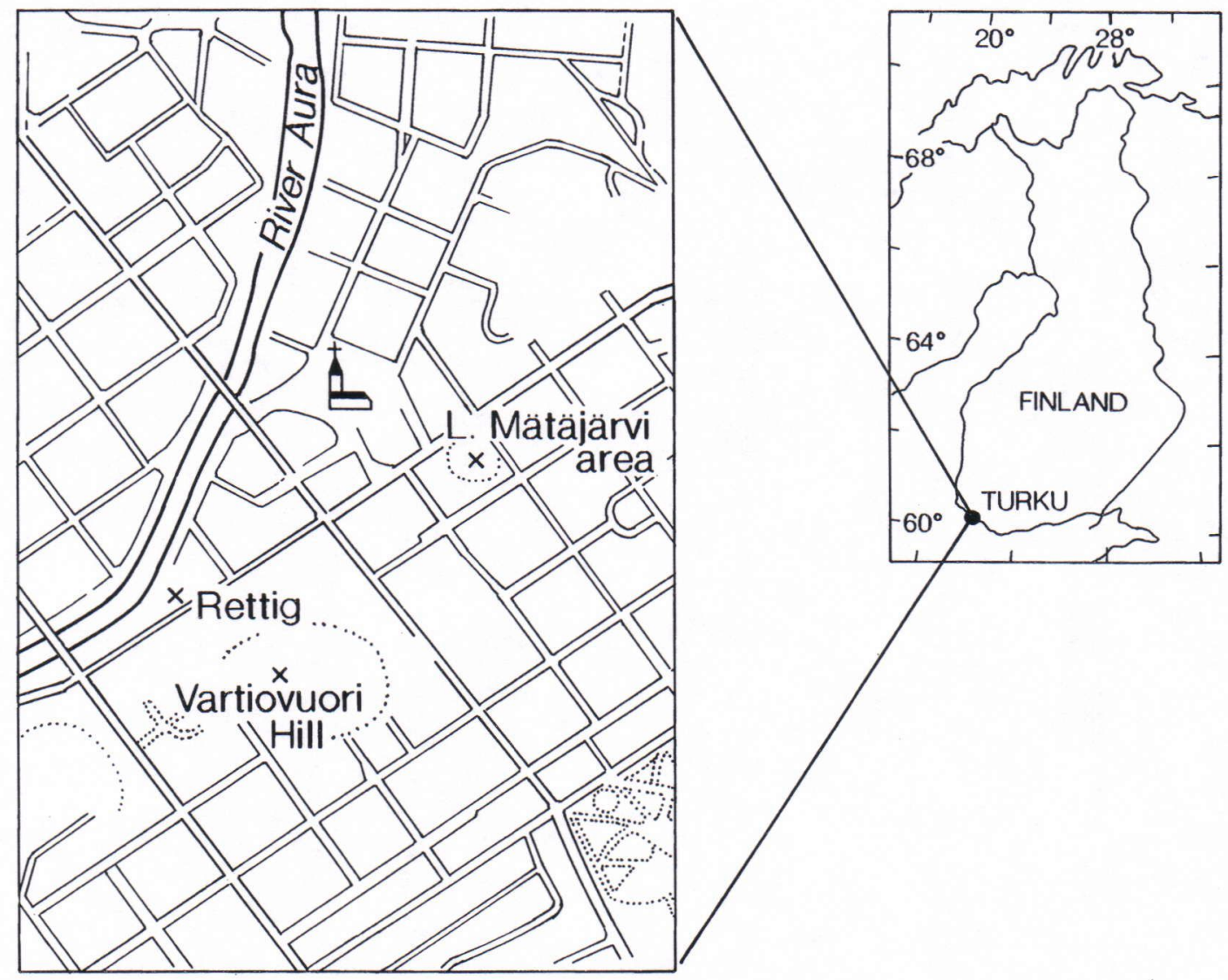

Figure 1. Location of the research area in the town of Turku, SW Finland. 
The Rettig quarter lies only $0.5 \mathrm{~km}$ south of the former Lake Mätäjärvi (Fig. 1) the bottom deposits of which date to the 12th-18th centuries $\mathrm{AD}$ and were investigated in an interdisciplinary project in the mid-1980s (Lempiäinen 1985, 1989, Vuorela 1985, 1989, Lempiäinen et al. 1986, Niemi 1989, Salonen et al. 1989, Vuorisalo \& Virtanen 1989). These investigations, together with the present Rettig material, shed light on the palaeoecology of the medieval town of Turku.

\section{GEOLOGICAL BACKGROUND OF THE STUDY AREA}

The Turku area was deglaciated about 10900 radiocarbon years ago (Glückert 1976, 1977,
Ignatius et al. 1980). The waters of the Baltic Yoldia Sea, which was then connected to the Atlantic via the Närke Strait in southern central Sweden, inundated the newly emerged land (Alhonen 1979). The rate of land uplift was at its maximum just after the retreat of the ice. During the process of emergence, the areas were gradually transformed from open sea to archipelago and to unbroken land (Fig. 3).

The level of the Yoldia Sea was located more than $100 \mathrm{~m}$ higher than present sea level. The water was brackish marine or brackish mixed with glacier freshwater. Uplift was fast during the Yoldia Sea stage in Finland and Sweden, and the connection between the Baltic basin and the ocean became closed. The next event in the history of the Baltic basin was a freshwater

B

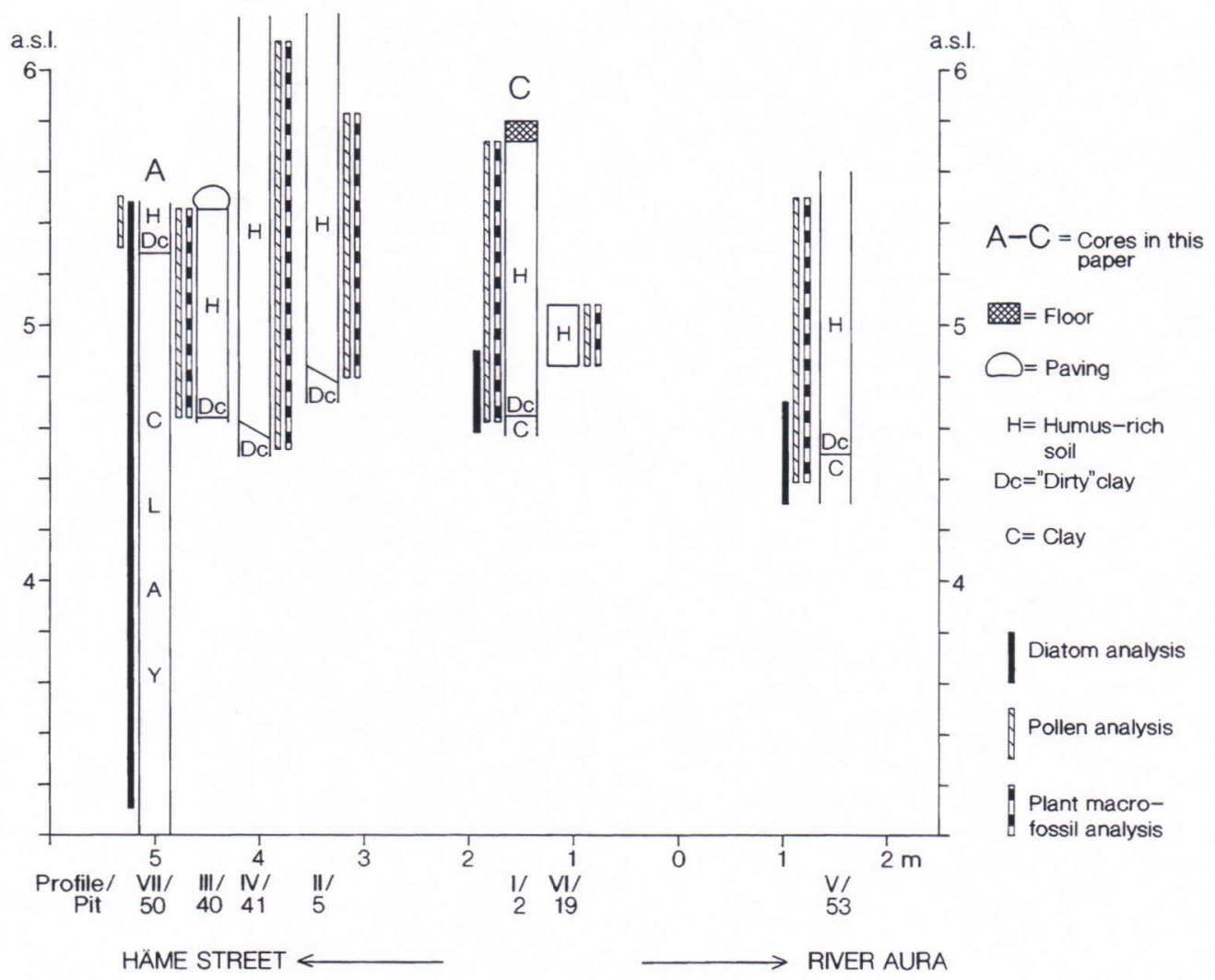

Figure 2. Location of cores investigated at the Rettig excavation site, drawn on a NW-SE axis. 
A
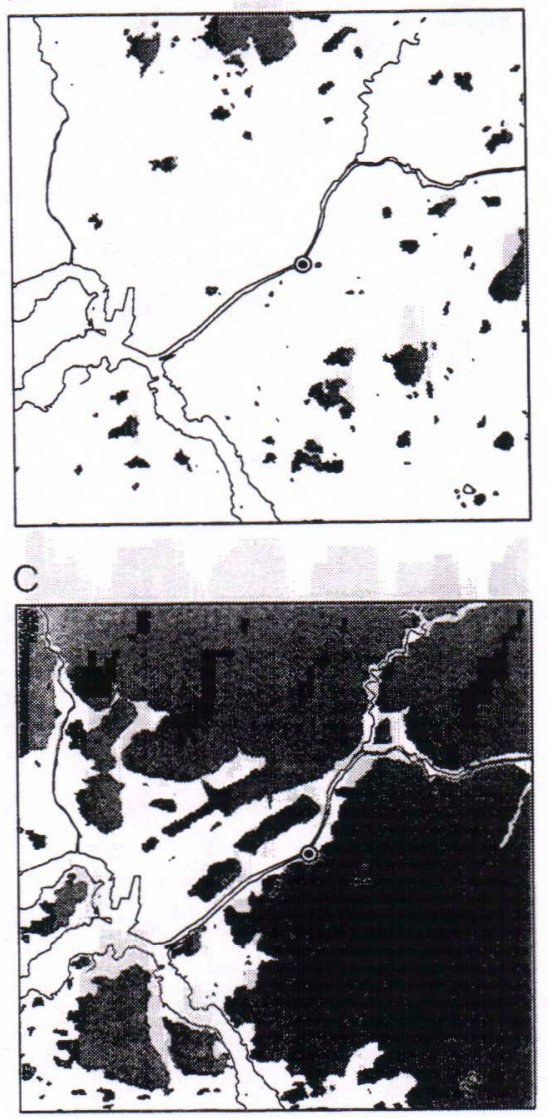

B

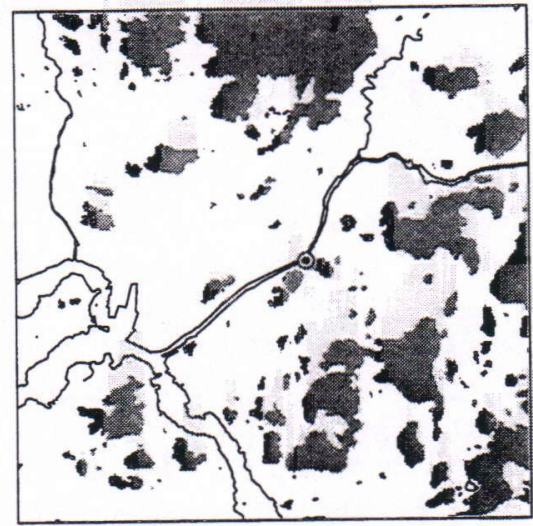

D

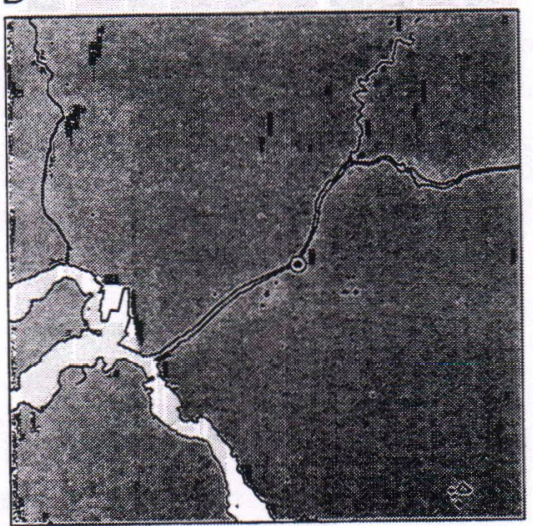

Figure 3. Development of landscape in the course of uplift in the Turku district. A $=35 \mathrm{~m}$ contour line, sea level c. 5800 years ago; $B=25 \mathrm{~m}$ contour line, sea level c. 4200 years ago; $C=10 \mathrm{~m}$ contour line, sea level c. 1800 years ago; $D=$ Present distribution land/sea. $\mathbb{O}=$ Sample site by the River Aura

stage, called the Ancylus Lake (9500-8500 B.P.). This lake was characterized by a (clear water) diatom flora indicating a large alkaline freshwater basin. The oldest shorelines (about $80 \mathrm{~m}$ a.s.1.) in the Turku area were formed during the Ancylus Lake stage (Glückert 1976). The transgressive Ancylus Lake burst through the straits of Denmark, and with the formation of a new connection with the Atlantic the next stage, the Litorina Sea, was formed (7800-8000 B.P.) in the Baltic basin. This sea was larger and more saline than the Baltic Sea has since been. The highest shoreline in the Turku area during the Litorina Sea stage was at c. $50 \mathrm{~m}$ a.s.1. (Glückert
1976). The Litorina Sea changed into the present-day brackish and smaller Baltic Sea without any clear ecological turning point.

\section{MATERIAL AND METHODS}

Samples were taken in 1994-1995 at the archaeological excavation site of the Rettig "Palace" in the centre of the town of Turku, southwestern Finland $\left(60^{\circ} 27^{\prime} \mathrm{N}, 22^{\circ} 16^{\prime} \mathrm{E}\right.$; topographical map No. 1043 12, $x=6704$ 96, y 1570 26; Fig. 1). 
The general stratigraphy of the site is clay (variably up to $5.30 \mathrm{~m}$ a.s.l. in core A) overlain by some $15 \mathrm{~cm}$ of terrestrial mineral soil in which the cultural layer is developed (Fig. 2). The cultural layer is genetically very variable, containing irregular strata rich in charcoal, mor$\operatorname{tar}$ and/or brick fragments alternately with humus rich material. The "dirty" grey clay deposited between the clay and the humic shore deposits of pre-urban days may have been affected by wave action and other natural forces during approximately the first centuries $\mathrm{AD}$. It is also possible that the cultural layer was partly removed in the course of building in medieval time. For precise stratigraphy of the cores B and C see also Fig. 4.

Like most urban cultural layers, the stratigraphy of the profiles varies horisontally and vertically, being in Core A clay at 3.10-5.30 m a.s.1. and "dirty" clay (terrestric mineral soil) at 5.30 $5.45 \mathrm{~m}$ a.s.l.

The material was prepared for pollen analysis using $\mathrm{KOH}$ and cold HF methods (Faegri \& Iversen 1989) on $5 \mathrm{~cm}^{-3}$ samples. Coarse material was removed by sieving. For the determination of pollen concentration values, recent Lycopodium spores were added (Stockmarr 1971). The pollen data were divided into groups as follows: deciduous trees, conifers, broad-leaved trees, shrubs (Fig. 11), aquatics and shore meadow vegetation, natural

\section{a.s.I. CORE B, RETTIG Turku}

$\mathrm{m}$

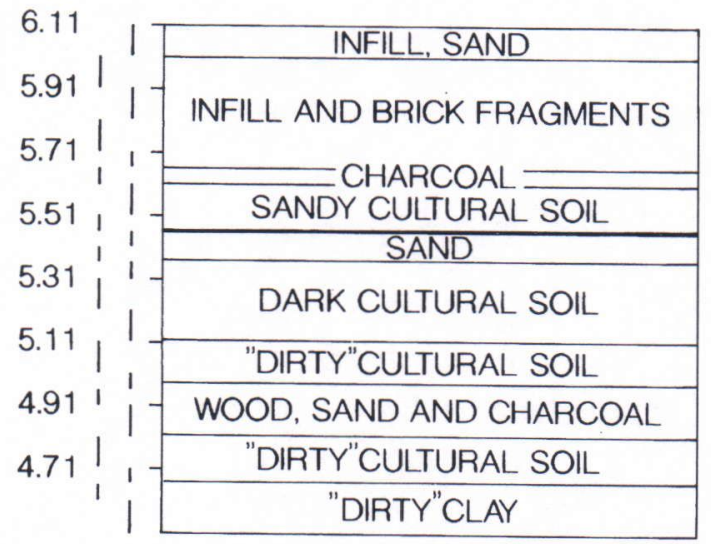

mineral soil vegetation (Fig. 12), open forest herbs and settlement indicators (Fig. 13).

The method described by Battarbee (1979) was used for diatom and phytolith analyses. The siliceous fossils were fixed with hyrax.

Pollen and macrofossil analyses were made on the same cores. The volume of subsamples for plant macrofossil analysis ranged from 0.5 to 11 . The material was floated in a saturated $\mathrm{NaCl}$ solution with an $\mathrm{H}_{2} \mathrm{O}: \mathrm{NaCl}$ ratio of $3: 1$. The plant remains were picked up using a stereomicroscope (WILD M5). Remains were stored in 50\% alchohol.

Pollen grains were identified mainly on the basis of the work of Erdtman et al. (1961) and Moore et al. (1991) and the plant nomenclature is that used by Hämet-Ahti et al. (1986). For identification of diatoms the publications of Mölder \& Tynni (1967-1973), Tynni (1975-1980) and Krammer \& Lange-Bertalot (1986-1991) were used. Some taxa were later transferred to the new genera described by Round et al. (1990). New names are given together with the old ones in the text. Plant macroremains were identified on the basis of studies of Beijerinck (1947), Körber-Grohne (1967) and Behre (1976, 1983, 1991). Macrofossil data from the Turku area published earlier by Lempiäinen $(1985,1988,1989,1995 a, b)$, Valo (1993) and Aalto (1994) were also referred to. Phytoliths

\section{CORE C, RETTIG Turku}

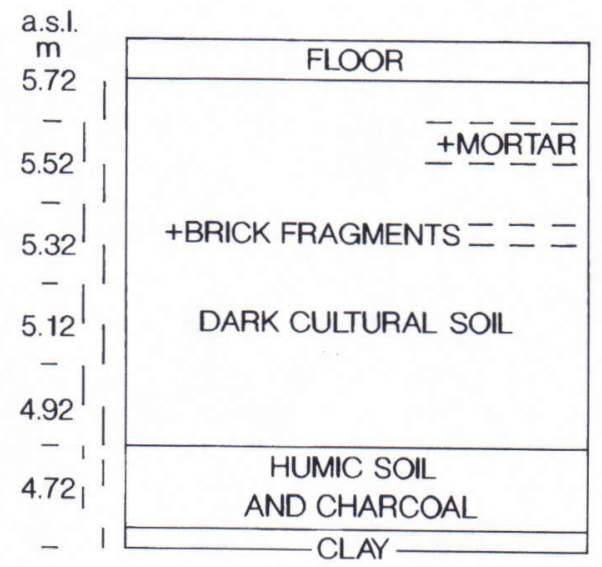

Figure 4. Stratigraphies of Cores B and C. 
51 I. Vuorela et al.

COHE A, HE I IIG lurku

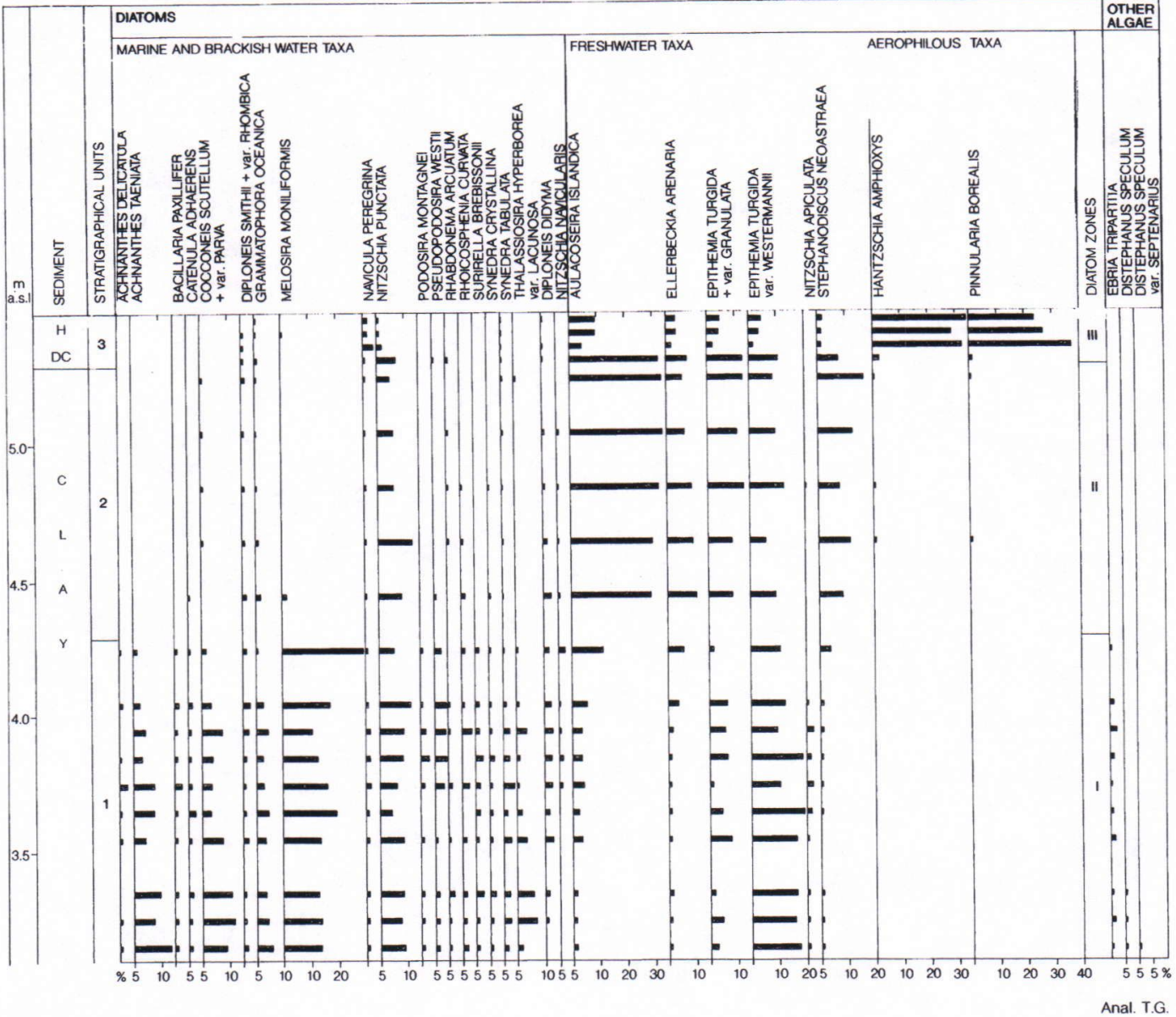

Figure 5. Diatom spectra including species representing $>2 \%$ of total diatom sum and other algae in Core A of the Rettig excavation site. DC = "Dirty" clay, $H=$ Humus rich soil.

were determined according to the morphotypes described by Powers et al. (1988).

\section{RESULTS}

\section{Diatom stratigraphy}

The most important results from Core A are given as diagrams (Figs 5-7). The most common diatoms (more than $2 \%$ of the total diatom sum) are shown in Fig. 5. The list of diatoms noted from the Rettig site is presented in Vuorela et al. (1996). The diatoms were classified as marinebrackish and freshwater species, and the latter group further as freshwater large lake species and ordinary freshwater species (Fig. 6). Depending on the habitat of the diatoms, they were divided into plankton, lagoonal, littoral and aerophilous species (Fig. 7). The diatom succession was divided into three zones (I-III).

Zone I (3.15-4.30 m a.s.1.) contains sediments deposited in the Baltic Litorina Sea. Diatom 
species typical of the littoral areas of the Litorina Sea dominate (Eronen 1974, Ignatius \& Tynni 1974, Miller \& Robertsson 1979). The most characteristic species are Melosira moniliformis (Müller) Agardh, Cocconeis scutellum Ehrenberg including var. parva (Grunow) Cleve and Nitzschia punctata (W. Smith) Grunow (= Tryblionella punctata W. Smith). Achnanthes deli- catula (Kützing) Grunow including var. hauckiana (Grunow) Lange-Bertalot, Diploneis didyma (Ehrenberg) Cleve, Navicula peregrina (Ehrenberg) Kützing and Nitzschia apiculata (Gregory) Grunow (= Tryblionella apiculata Gregory) also occur frequently. Some planktonic diatoms such as Chaetoceros muelleri Lemmermann, Chaetoceros spp., Coscinodiscus asteromCORE A, RETTIG Turku

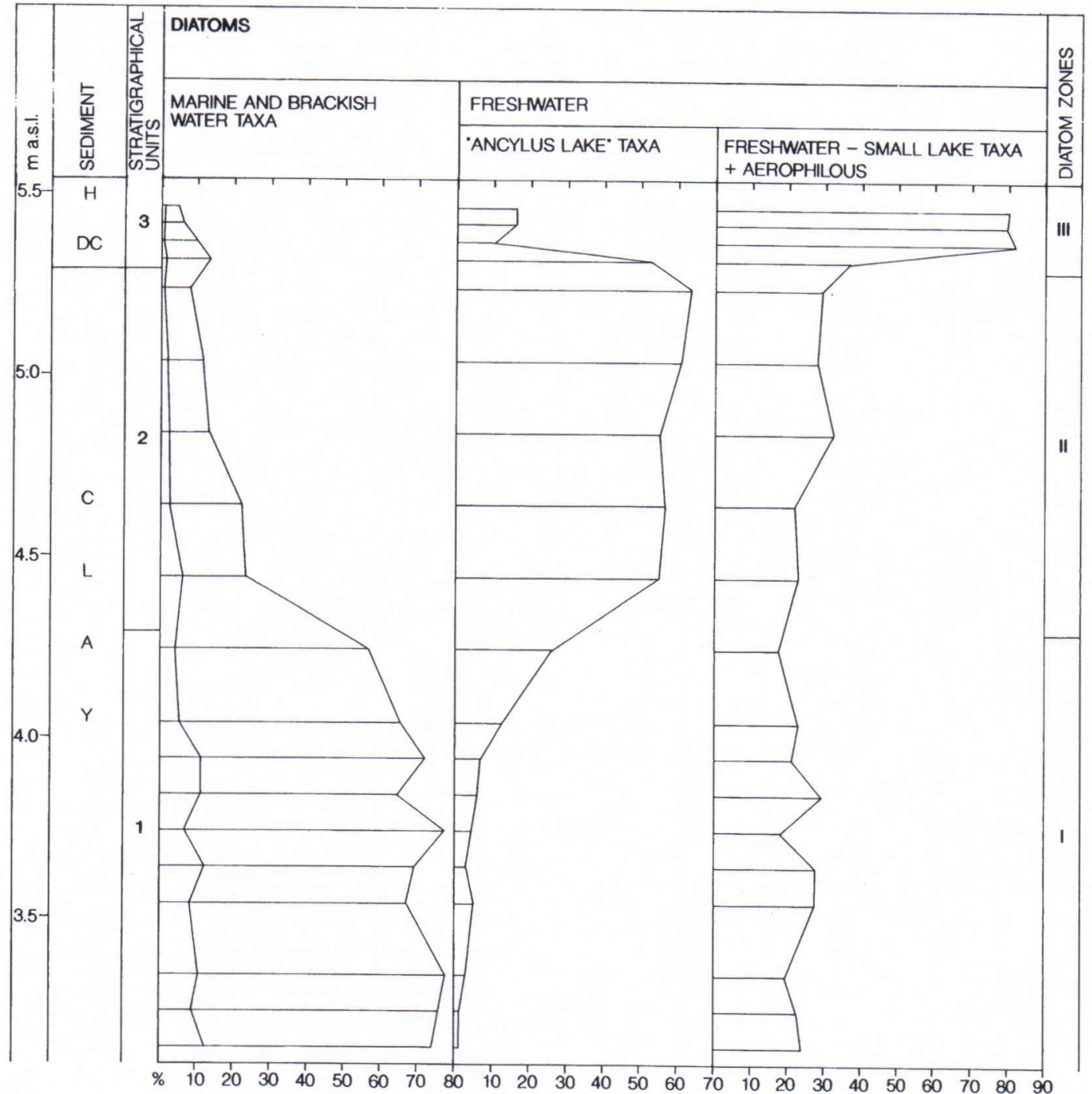

Anal. T.G.

Figure 6. Division of diatom flora of Core A according to their salt tolerance. DC = "Dirty" clay, H=Humus rich soil. 
53 I. Vuorela et al.

CORE A, RETTIG Turku

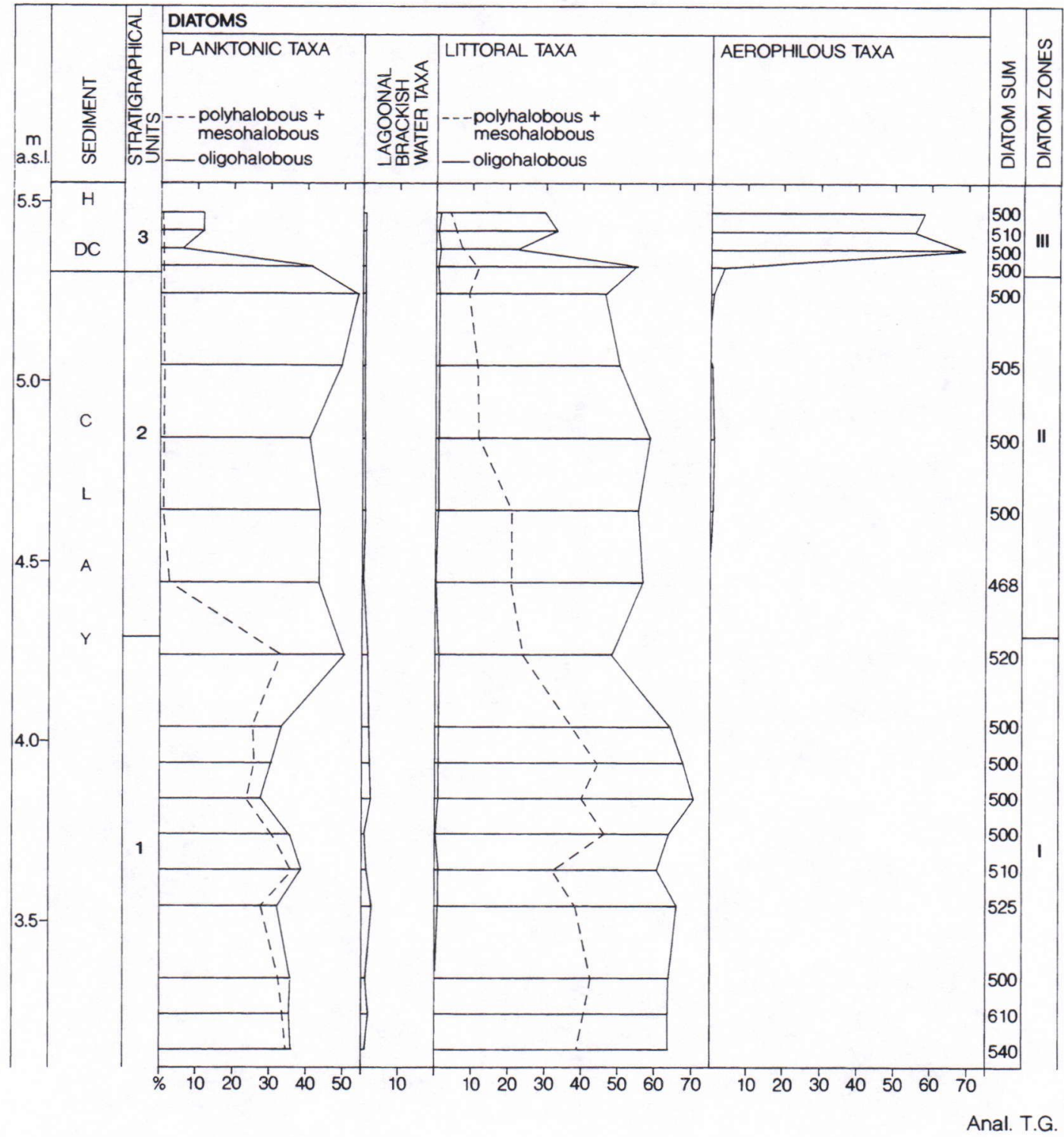

Figure 7. Ecological division of the diatom flora of Core A (according to different habitats). DC = "Dirty" clay, $H=$ Humus rich soil.

phalus Ehrenberg, Podosira montagnei Kützing Pseudopodosira westii (W. Smith) SheshukovaPoretzskaya and Thalassiosira hyberborea var. lacunosa (Berg) Hasle were also encountered. Typical of the lagoonal shallow water phase of the Litorina Sea are Campylodiscus clypeus Ehren- berg, C. bicostatus W. Smith, Nitzschia scalaris (Ehrenberg) W. Smith and Surirella striatula Turpin (Florin 1946, Eronen 1974).

Some freshwater diatoms were also found. The most characteristic species was Epithemia turgida var. westermannii (Ehrenberg) Grunow, 

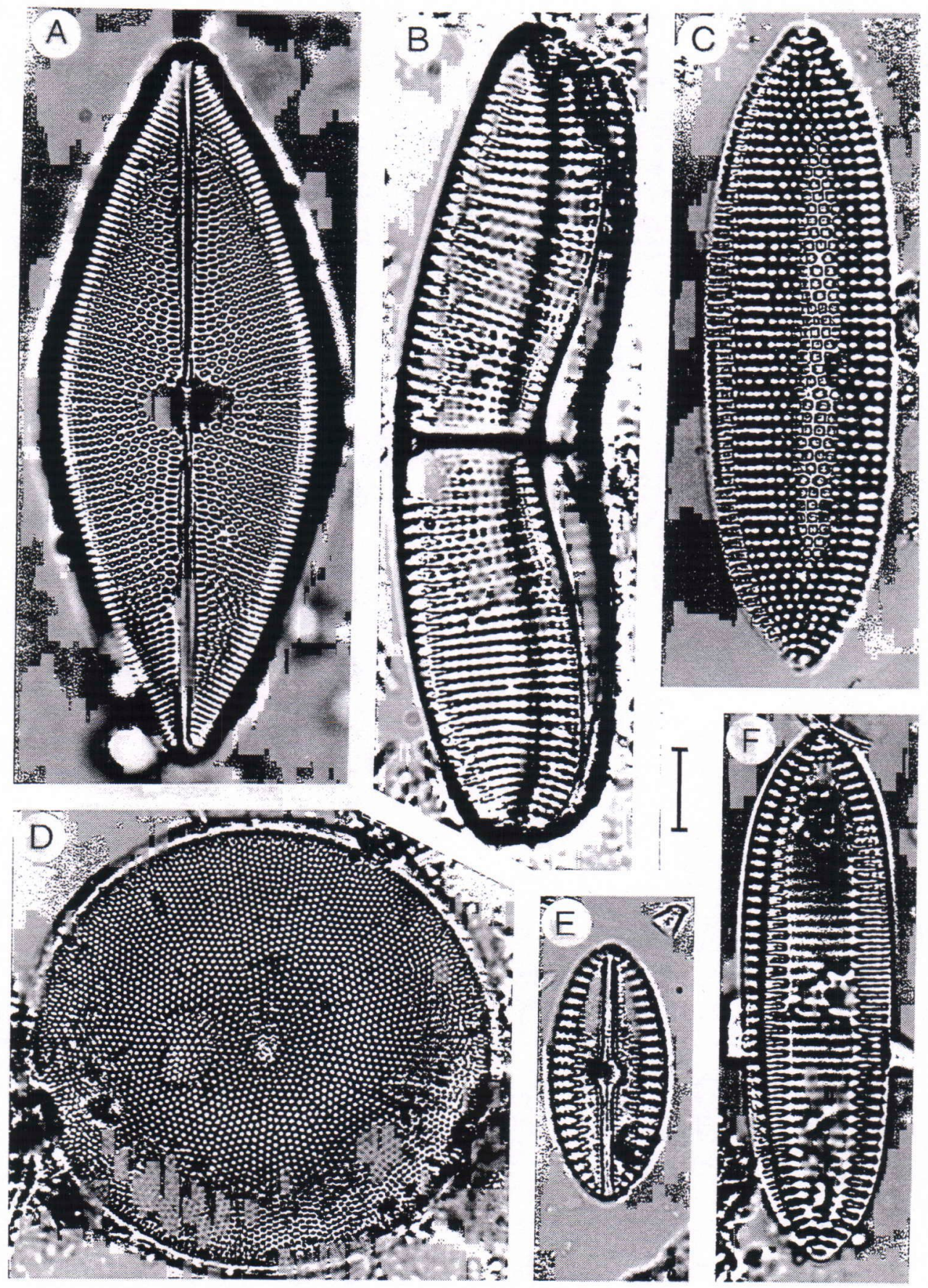

Figure 8. Diatoms represented in the samples analysed. LM photos. Scale bar $=10 \mu \mathrm{m}$. A. Navicula marina Ralfs (= Petroneis marina (Ralfs in Prithard) D.G.Mann, B. Achnanthes longipes Agardh, C. Nitzschia punctata (W. Smith) Grunow (Tryblionella punctata W. Smith), D. Thalassiosira baltica (Grunow) Ostenfeld, E. Diploneis mauleri (Brun) Cleve, F. Nitzschia navicularis (Brébisson) Grunow ((Tryblionella navicularis (Brébisson ex Kützing) Ralfs in Pritchard. Photo: T. Grönlund. 
which was also interpreted as a halophilous taxon. It is common in littoral sediments of the Litorina Sea (e.g. Miller \& Robertsson 1979).

Ebria tripartita (Schumann) Lemmermann, of the order Ebriales, was found occasionally, together with some silicoflagellates such as Distephanus speculum (Ehrenberg) Haeckel and var. septenarius (Ehrenberg) Joergensen, which are also marine plankton algae.

Zone II is composed of clay at the $4.30-5.30$ $\mathrm{m}$ a.s.l. The diatom assemblage differs clearly from that in Zone I, although diatoms indicating saline and brackish water are present, freshwater diatoms dominate. Aulacoseira islandica (Müller) Simonsen is the most common. It belongs to a diatom flora of the Ancylus Lake which includes Cocconeis disculus (Schumann) Cleve, Cymatopleura elliptica (Brébisson) W. Smith, Cymbella aspera (Ehrenberg) Peragalli, C. langeolata (Ehrenberg) Cleve, Diploneis maulerii (Brun) Cleve, Ellerbeckia arenaria (Moore) Crawford, Epithemia hyndmannii W. Smith, Gyrosigma attenuatum (Kützing) Rabenhorst and Opephora martyi Heribaud (= Martyana martyi (Heribaud) Round).

Zone III represents the uppermost part of the core at $5.30-5.45 \mathrm{~m}$ a.s.l. and contains a lower number of diatoms than the rest of the core. Aerophilous Hantzschia amphioxys Ehrenberg (Grunow) and Pinnularia borealis Ehrenberg are dominant. Among other aerophilous species noted are Navicula cohnii (Hilse) Lange-Bertalot, N. contenta Grunow, $N$. mutica Kützing (= Luticola mutica (Kützing) D.G. Mann), N. pusilla W. Smith (= Cosmioneis pusilla (W. Smith) D.G. Mann \& A.J. Stickle) and Pinnularia lata (Brébisson) W. Smith. Ellerbeckia arenaria was also found. It belongs to the flora of the Ancylus Lake but is also aerophilous in biotype, thriving especially on sandy shores. Aerophilous diatoms indicate low moisture environment.

\section{Conclusions drawn from the diatom strati- graphy}

The clay bed at the Rettig site can be divided into two stratigraphical units based on their dia- tom assemblages. The formation of these two units can be attributed to crustal uplift. The species found in the lower unit, dominated by Litorina diatoms, have been typically deposited in a shallow water environment in a sheltered archipelago. In the upper unit, made up of terrestrial sediments, Litorina diatoms are in minority while the dominant species have clearly been redeposited from old Ancylus Lake sediments that had formed about 9000 years ago. Due to land uplift, these sediments were later exposed to aerial erosion.

The upper humic part of the core, Unit 3, indicates a supra-aquatic environment just after the emergence of the new land, which was kept wet by sporadic floods and waves. Only aerophilous diatoms could grow under such conditions.

\section{Pollen analysis}

\section{Local pollen taphonomy}

In addition to the pollen produced by local vegetation, lots of non-anthropogenic pollen from the catchment was brought in by floods of the River Aura. Palaeoecologically, however, the most important pollen taxa, the settlement indicators, mainly represent the riverside habitation closely connected with the history of Turku. Such mixing is therefore not misleading in the interpretation of the results. On one hand, it is clear that large quantities of pollen grains were washed into the river, along with mineral soils and on the other hand, pollen content was partly affected by rainwater flowing from the adjacent hill of Vartiovuori (Fig. 1). The overall effect is probably to underestimate the cultural indicators and to overestimate the forest.

During the last few centuries, local human activity has modified the landscape and vegetation in various ways. The stone-paved narrow streets between the buildings have acted as tunnels along which the pollen has been trasported by wind. Rainwater streams have used the same routes. 
CORE B, RETTIG Turku

RELATIVE POLLEN FREQUENCY

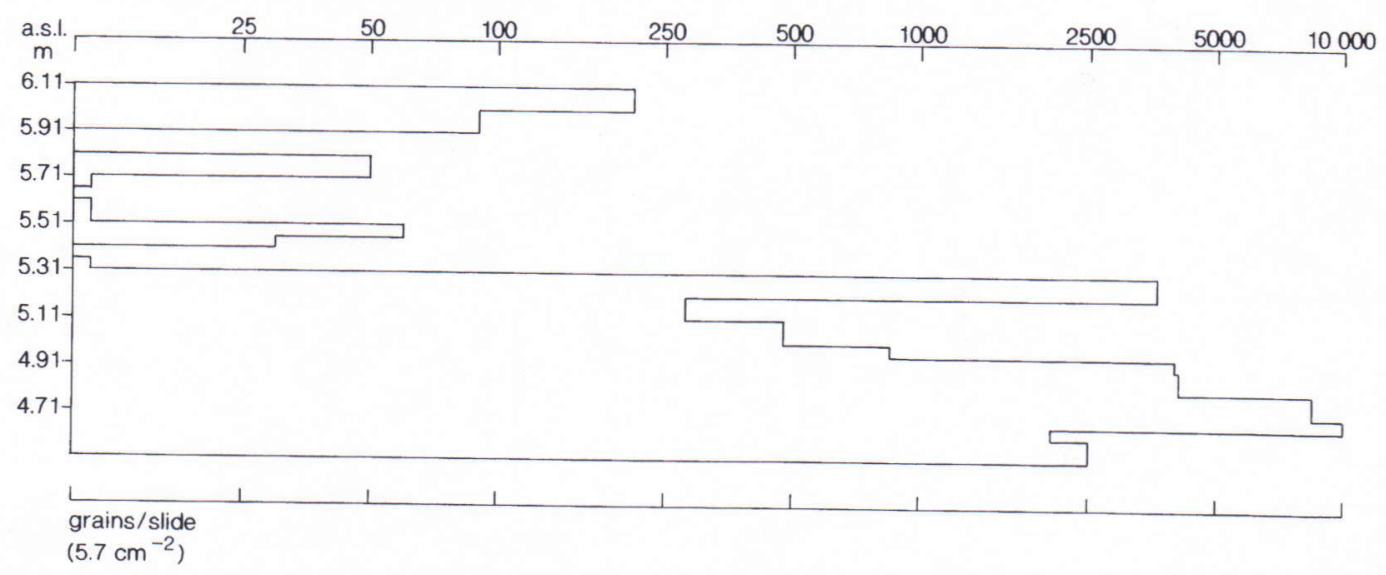

Figure 9. Relative pollen frequency of slides $\left(5.7 \mathrm{~cm}^{2}\right)$ investigated from Core $B$.

Pollen contamination has also taken place through material brought into the town by the inhabitants and their domestic animals. Such sources of pollen have included crops, roofing, fodder, bedding, wild food and dung (Clapman \& Scaife 1988).

Oxidation and drying of soil layers have been important taphonomic processes which lead to pollen corrosion, as do frost and human activity

CORE B, RETTIG Turku

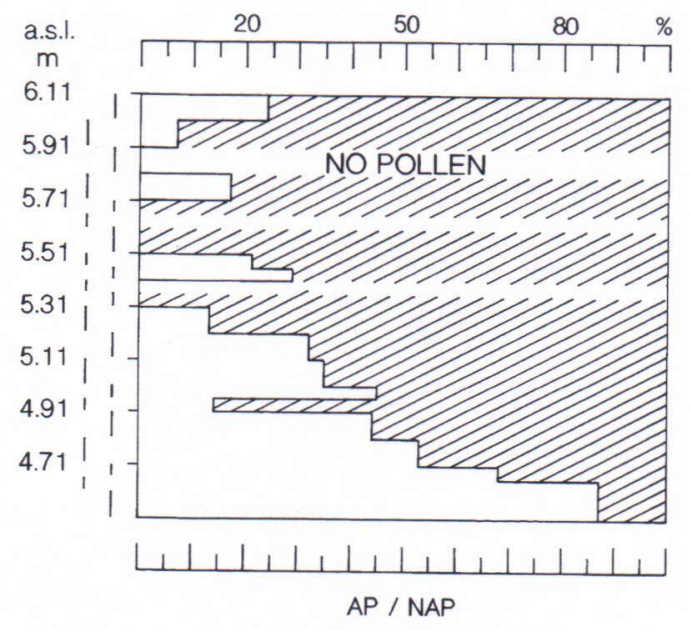

Figure 10. Fluctuations in the AP/NAP ratio in Core B. at urban sites ( $c f$. Vuorela 1991, fig. 2). Even though minor contamination of the mineral soil can seldom be confirmed, the material used as infill in the building process is clearly distinguishable due to its more or less total lack of pollen grains. Other palaeoecological methods such as macrofossil analysis may produce useful information on such material.

\section{Pollen concentration}

The relative pollen concentration values of Core B are presented on a logarithmic scale (Fig. 9) giving numbers of pollen grains on each cover slide $\left(5.7 \mathrm{~cm}^{2}\right)$. Even this imprecise scale shows great variation, making it easy to draw the boundary between the well-preserved, more humic lower part and the dryer upper part with corroded pollen grains at $5.30 \mathrm{~m}$ a.s.1. At the intervals 5.36-5.41 m, 5.61-5.66 $\mathrm{m}$ and 5.81-5.91 m, there was no pollen noted.

The same division of profile $\mathrm{B}$ is also evident in the AP/NAP ratio (Fig. 10), which clearly reflects the local increase in human impact. In the bottommost subsample, AP accounts for $87 \%$ of total pollen but decreases steadily to $14 \%$ at the $5.21 \mathrm{~m}$ level, which already represents urban 
I. Vuorela et al.

CORE B. RETTIG Turku

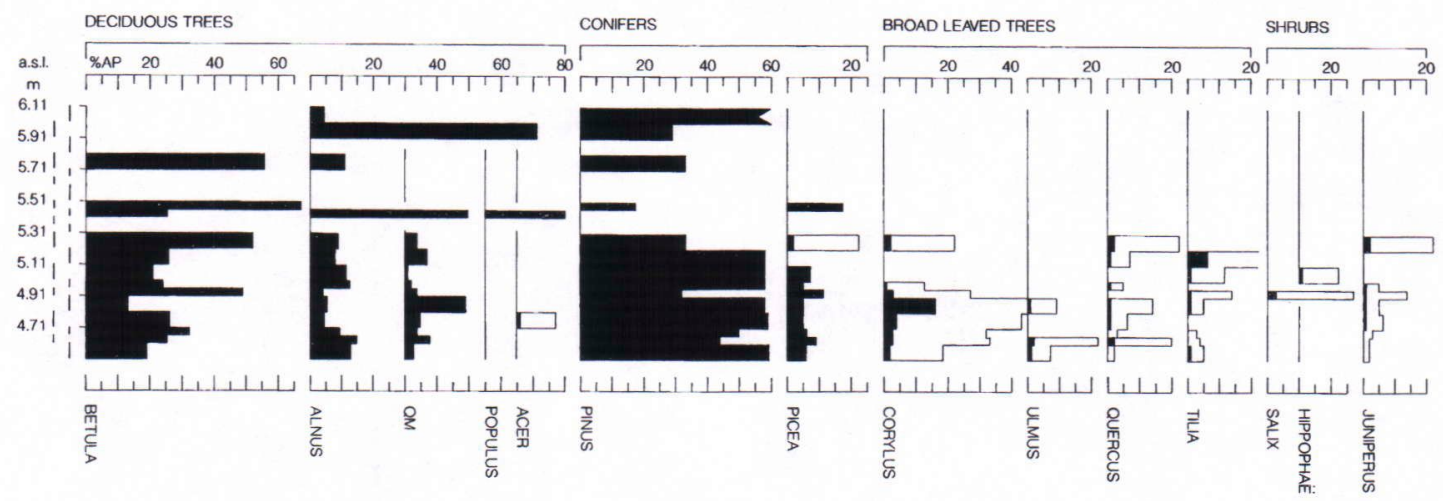

Anal. I.V.

Figure 11. Relative tree and shrub pollen frequencies in Core B.

settlement. Later, the herb pollen frequencies reach $100 \%$ at several levels. This development, together with the pollen taxa, is similar to that noted in material from Lake Mätäjärvi (Vuorela 1985), less than $1 \mathrm{~km}$ from the Rettig site (Fig. 1 ), and interpreted as indicating forested meadows which preceded urban environments.

\section{Relative pollen frequencies}

In the lower half of the core (Fig. 11) relative pollen frequencies of conifers dominate. Pinus remains steady at c. $65 \%$ AP whereas the pollen frequencies of deciduous trees are more evenly divided between Betula (20-50\%), Alnus $(5-15 \%)$ and broadleaved deciduous trees (1-18\%). The relatively high frequencies of the last-mentioned group, dominated first by Corylus, then by Tilia, evidently reflect local grazing on forested meadows and can thus be correlated with the Mätäjärvi material. Such activity seems to have taken place over a broader area on the banks of the River Aura during the period preceding urban habitation, an interpretation that is supported by the regular occurrence of Juniperus pollen grains at this level. Pollen grains of Hippophä̈ at the $5.01 \mathrm{~m}$ level serve as important evidence of the former distribution of this shrub, which nowadays grows only on the west coast of Finland from latitude $60^{\circ} 40^{\prime}$ northwards and in the Aland Islands
(Hultén 1971) and indicates specific coastal conditions.

From the $5.31 \mathrm{~m}$ level upwards no pollen of broadleaved trees were found in Core B. Instead, the pollen frequencies of Alnus, Populus and Picea fluctuated strongly. Since the decrease in QM species is on a minor scale in most cores (e.g. Core I/2; Vuorela et al. 1996) these changes most probably reflect intense local human activity. The results from the $5.41 \mathrm{~m}$ level upwards are, however, based on relatively low pollen concentration values (cf. Fig. 9) and thus are only partly comparable with those from the lower part of the profile.

Among aquatics (Fig. 12), only Nymphaea is represented in Core B, although Isoëtes lacustris, Potamogeton and Sparganium are also present in the local pollen flora (cf. Table 3).

Pollen of Caltha palustris represents moist shore vegetation, as does most of the pollen of Cyperaceae, Thalictrum, Filipendula, Cornus and Valeriana.

The natural mineral soil vegetation is dominated by Poaceae, even though this pollen type also includes Phragmites australis. Among the rich pollen flora of zoogamous herbs, Ranunculceae (+Ranunculus acris), Rosaceae, Rubiaceae, Fabaceae, Achillea-type, Centaurea scabiosa, Succisa pratensis, Aster-type, Caryophyllaceae, Apiaceae and Campanulaceae refer to forested 
CORE B. RETTIG Turku

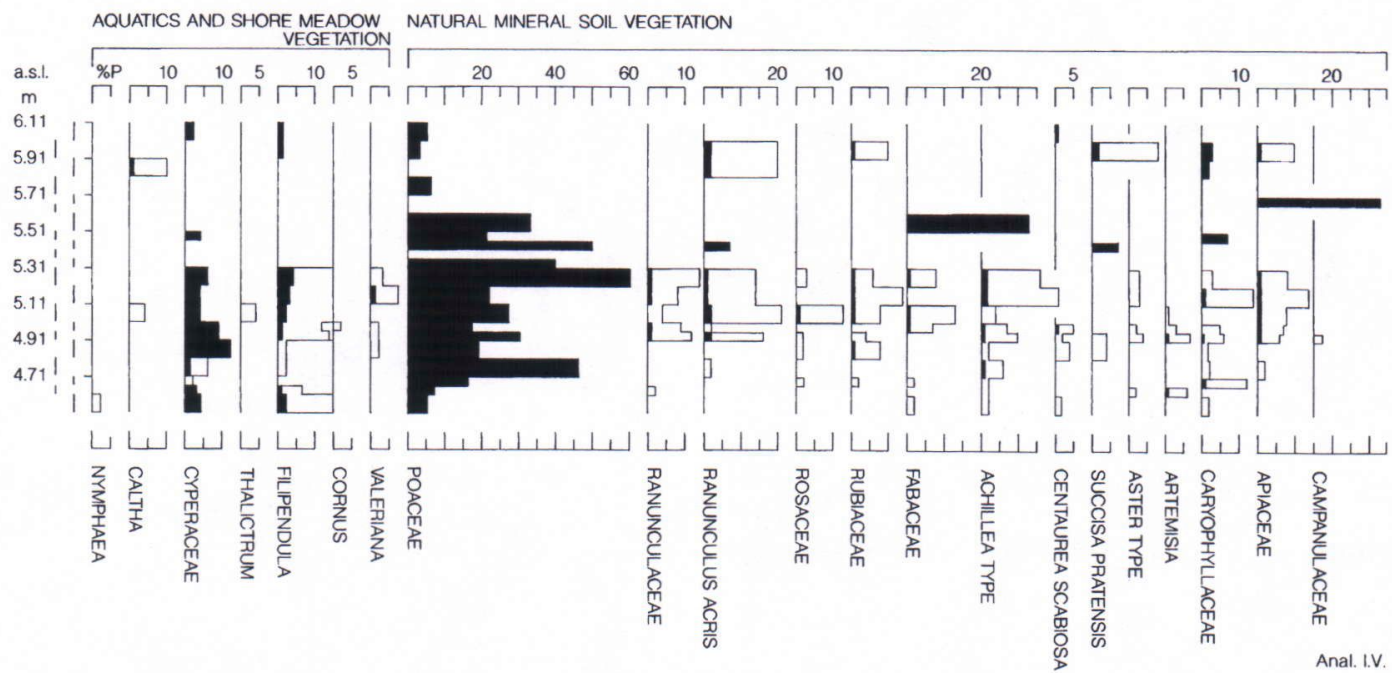

Figure 12. Relative pollen frequencies $(\% P)$ of aquatics, shore meadow vegetation and other mineral soil herbs in Core $B$ of the Rettig material.

meadows, while Artemisia is typical of settled areas.

Open forest vegetation (Fig. 13) is represented by Sphagnum, Polypodiaceae, Melampyrum, Pteridium, Anemone-type, Equisetum, Eri- caceae and Calluna. The boundary between this group and the natural mineral soil vegetation is not clear.

Settlement indicators are overwhelmingly dominated by Cerealia, which reaches $40 \% \mathrm{P}$ at the

CORE B, RETTIG Turku

OPEN FOREST VEGETATION SETTLEMENT INDICATORS

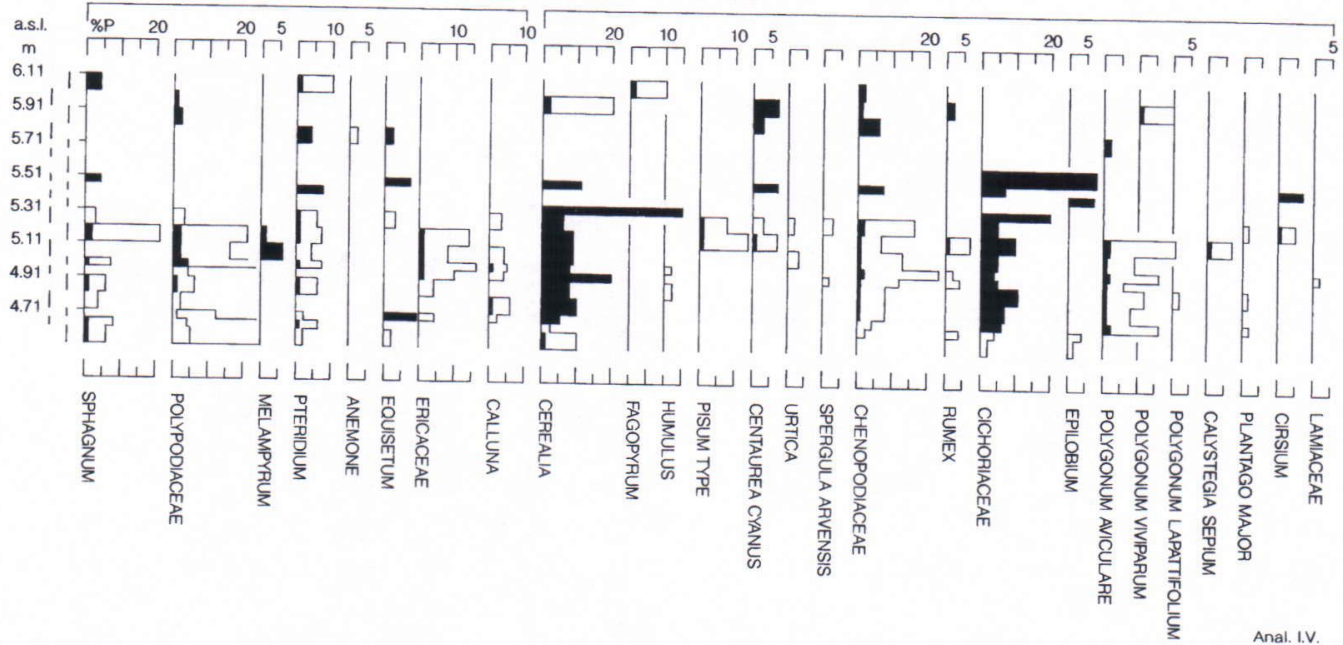

Figure 13. Relative pollen frequencies (\% P) of open forest herbs and settlement indicators in Core B of Rettig material. 
Table 1. Macrofossil plant remains from the deposit in Rettig 1994, Core C. The finds are seeds or fruits if not otherwise mentioned.

\begin{tabular}{|c|c|c|c|c|c|c|c|c|c|c|c|c|c|c|}
\hline Plant species & $\begin{array}{l}\text { Depth } \\
5.72\end{array}$ & m $\begin{array}{c}\text { a.s.1. } \\
5.62\end{array}$ & 5.52 & 5.42 & 5.32 & 5.22 & 5.12 & 5.02 & 4.92 & 4.82 & 4.72 & 4.62 & 4.47.4.27 & sum \\
\hline \multicolumn{15}{|l|}{ A. Plants used by man } \\
\hline Linum/Cannabls/tibre & $\therefore$ & $:$ & : & . & : & 1 & : & : & ! & : & : & : & : & $i^{10}$ \\
\hline Cannabis sativa & . & . & 1 & . & . & : & . & . & - & . & . & . & . & 1 \\
\hline Humulus Iupulus & - & - & . & 2 & 1 & 3 & 2 & - & 17 & 3 & . & . & . & 28 \\
\hline Flous carica & - & - & . & . & . & . & 1 & - & . & . & - & . & - & 1 \\
\hline Fragaria vesca & 2 & . & 33 & 5 & 6 & 3 & 8 & 12 & 2 & . & . & 1 & . & 72 \\
\hline Hyoscyamus niger & - & - & 1 & - & - & - & - & - & - & - & - & - & . & 1 \\
\hline Myrica gale & - & - & - & - & 1 & : & 1 & : & : & . & - & . & - & 2 \\
\hline Vaccinium myrtillus & - & - & - & - & - & 1 & . & 2 & 2 & . & - & . & . & 5 \\
\hline Vaccinfium sp. & - & - & - & - & - & $\because$ & - & : & : & - & - & 1 & - & 1 \\
\hline \multicolumn{15}{|l|}{ 8. Trees and shrubs } \\
\hline Corylus avellana & 6 & - & 4 & . & 2 & 1 & . & - & . & . & . & . & . & 13 \\
\hline Juniperus communis & - & - & . & - & 1 & $i$ & . & - & . & . & - & - & - & 2 \\
\hline Picea ables & - & & $1^{*}$ & 1 & 1 & - & 1 & - & - & - & - & - & $1^{*}$ & 5 \\
\hline Quercus robur & - & - & . & - & . & . & - & - & 2 & - & - & - & - & 2 \\
\hline Rosa sp. & - & - & - & - & 1 & - & - & - & . & . & . & . & . & $i$ \\
\hline Sorbus aucuparia & - & - & - & - & : & 1 & . & . & . & . & . & . & - & $i$ \\
\hline Tllia cordata & . & - & . & - & - & . & . & - & - & . & - & - & - & : \\
\hline \multicolumn{15}{|l|}{ c. Weeds and ruderals } \\
\hline Agrostemma githago & . & . & . & . & 1 & 1 & . & 5 & 1 & . & . & . & . & 8 \\
\hline Atriplex patula & . & - & 6 & 1 & 4 & 8 & 5 & 1 & 1 & - & . & . & - & 26 \\
\hline Brassicaceae/Crucifera & . & - & . & . & : & - & 2 & . & . & . & . & . & . & 2 \\
\hline Brassica/Raphanus & . & . & - & . & 1 & 1 & . & - & . & - & - & . & - & 2 \\
\hline Centaurea cyanus & - & - & - & - & $\cdot$ & 1 & . & - & . & - & . & . & . & 1 \\
\hline Chenopodium album & 4 & 2 . & 42 & 10 & 15 & 48 & 34 & 27 & 4 & . & . & 4 & . & 190 \\
\hline Chrysanthemum segetum & : & . & 1 & - & . & - & 1 & - & : & . & . & . & . & 2 \\
\hline Cirsium anvense & . & - & $i$ & . & . & . & $i$ & . & . & . & . & . & . & 2 \\
\hline Cuscuta europaea & . & . & $i$ & 1 & . & 1 & $i$ & . & . & $1 \mathrm{kă}$ & . & . & . & 5 \\
\hline Fallopla convolvulus & . & . & . & . & . & 1 & : & . & . & and & . & . & . & 1 \\
\hline Galeopsls speciosa & . & - & . & 1 & . & 1 & 1 & . & . & . & 1 & 1 & . & 5 \\
\hline Galium sp. & . & - & 1 & : & . & : & : & . & . & . & : & . & . & 1 \\
\hline Lamium pupureum & . & - & 3 & . & . & . & . & 1 & . & . & . & . & . & 4 \\
\hline Lapsana communis & . & - & . & - & 1 & 1 & . & - & . & . & . & . & . & 2 \\
\hline Plantago major & . & - & . & . & 1 & : & 1 & . & . & . & . & . & . & 2 \\
\hline Poa annua & . & . & 1 & 2 & 4 & 3 & : & 1 & 1 & . & . & 2 & . & 14 \\
\hline Polygonum aviculare & . & . & 2 & 1 & 9 & 10 & 1 & $i$ & 5 & . & . & 1 & . & 30 \\
\hline Polygonum hydropiper & 1 & . & : & : & 1 & - & 3 & : & . & . & . & . & . & 5 \\
\hline Polygonum lapathifolium & . & - & . & . & 4 & 14 & . & 12 & 1 & . & . & 1 & . & 32 \\
\hline Polygonum persicaria & . & . & . & . & 1 & - & . & . & . & . & . & : & . & 1 \\
\hline Prunella vulgaris & . & . & 1 & 2 & : & . & . & . & 2 & . & . & . & . & 5 \\
\hline Ranunculus acris & . & - & . & . & . & - & 2 & . & . & - & . & . & . & 2 \\
\hline Ranunculus repens & . & - & - & - & 2 & 1 & : & 3 & . & . & . & . & . & 6 \\
\hline Ranunculus sceleratus & . & . & 38 & 24 & 15 & 1 & 1 & 2 & . & . & . & . & . & 81 \\
\hline Rumex acetosella & . & . & . & - & - & : & : & $i$ & . & . & . & . & . & 1 \\
\hline Solanum nigrum & . & - & 1 & . & . & . & . & : & . & . & . & . & . & 1 \\
\hline Sonchus arvensis & . & . & : & . & . & 12 & . & . & . & . & . & . & . & 12 \\
\hline Spergula arvensis & . & - & 1 & . & . & $\cdot$ & 4 & 1 & . & . & . & . & . & 6 \\
\hline Stellaria graminea & . & . & 2 & . & . & . & . & $i$ & . & . & . & . & . & 3 \\
\hline Stellaria media & . & . & 3 & 2 & 7 & 9 & 16 & 6 & 1 & 1 & . & 1 & . & 46 \\
\hline Thlaspl arvense & . & . & . & . & : & . & 1 & . & : & : & . & . & . & 1 \\
\hline Tripleurospermum Inodorum & - & - & . & . & 1 & . & . & . & . & - & . & . & . & $i$ \\
\hline Untica diolica & . & . & 49 & 45 & . & . & . & . & . & . & . & . & . & 94 \\
\hline Untica urens & . & 2 & 2 & . & . & . & 1 & . & . & . & . & . & . & 5 \\
\hline
\end{tabular}




\begin{tabular}{|c|c|c|c|c|c|c|c|c|c|c|c|c|c|c|}
\hline & $\begin{array}{l}\text { Depth } \\
5.72\end{array}$ & 5.62 & 5.52 & 5.42 & 5.32 & 5.22 & 5.12 & 5.02 & 4.92 & 4.82 & 4.72 & 4.62 & 4.47-4.27 & sum \\
\hline Alchemilla sp. & 1 & - & - & - & . & . & - & 1 & - & . & - & . & . & 2 \\
\hline Cerastium sp. & . & - & - & - & - & . & - & : & - & . & . & 1 & . & $i$ \\
\hline Dianthus deftoides & - & - & - & : & . & - & - & 1 & : & - & - & - & . & 1 \\
\hline Filipendula ulmaria & - & - & - & 1 & - & . & . & . & 3 & - & . & - & . & 4 \\
\hline Hypericum maculatum & - & - & - & - & : & . & - & - & 1 & . & - & - & - & 1 \\
\hline Leucanthemum leucanthemum & . & : & $\cdot$ & - & 1 & . & 1 & . & . & . & . & . & . & 2 \\
\hline $\begin{array}{l}\text { Luzula campestris } \\
\text { Luzula pilosa }\end{array}$ & - & - & $\cdot$ & - & : & . & 4 & . & . & . & . & . & . & 4 \\
\hline $\begin{array}{l}\text { Luzula pilosa } \\
\text { Pimpinella saxitraga }\end{array}$ & - & - & - & : & 1 & 1 & - & - & - & - & . & - & . & 2 \\
\hline $\begin{array}{l}\text { Pimpinella saxifraga } \\
\text { Poa pratensis/trivialis }\end{array}$ & - & - & : & ; & : & 1 & - & - & - & - & . & - & - & 1 \\
\hline $\begin{array}{l}\text { Poa pratensis/trivialis } \\
\text { Poaceae }\end{array}$ & - & - & 1 & 1 & 8 & 4 & 5 & - & 6 & 2 & - & 1 & . & 28 \\
\hline $\begin{array}{l}\text { Poaceae } \\
\text { Sagina sp. }\end{array}$ & - & - & - & - & 2 & - & - & - & - & - & . & - & . & 2 \\
\hline $\begin{array}{l}\text { Sagina sp. } \\
\text { Scleranthus annuus }\end{array}$ & . & - & - & - & 1 & . & 1 & . & 3 & . & . & 3 & . & 8 \\
\hline Scleranthus annuus & . & . & . & . & : & 1 & : & . & . & . & . & . & . & 1 \\
\hline Solidago virgaurea & . & - & 1 & . & 2 & . & . & . & . & . & . & . & . & 3 \\
\hline Spergularia sp. & . & . & . & - & 1 & . & 4 & . & 1 & . & . & . & . & 6 \\
\hline Tritolium repens & . & . & - & $1 \mathrm{k}$ & - & & $1 \mathrm{ku}$ & - & : & . & . & $3 \mathrm{ku}$ & . & 5 \\
\hline Viola sp. & $\cdot$ & $\cdot$ & $\cdot$ & 1ko & $1 \mathrm{ko}$ & $2+2 \mathrm{ko}$ & $\cdot$ & 1 & $\cdot$ & $\cdot$ & $\cdot$ & 1 & $\cdot$ & 8 \\
\hline \multirow{2}{*}{\multicolumn{15}{|c|}{$\begin{array}{l}\text { E. Plants of shore, marsh and water } \\
\text { Batrachium so. }\end{array}$}} \\
\hline & & . & & 6 & 2 & & . & . & - & . & - & - & . & 9 \\
\hline Carex 2 & 5 & . & 27 & 29 & 36 & 99 & 39 & 50 & 3 & . & . & . & . & 288 \\
\hline Carex 3. & 1 & . & 4 & 10 & 12 & 5 & - & 3 & . & . & . & . & . & 35 \\
\hline Potentilla palustris & . & . & . & 6 & 1 & 5 & 1 & 1 & 2 & . & . & . & - & 16 \\
\hline Eleocharis palustris & . & . & 1 & . & 1 & 1 & 2 & : & : & . & . & . & . & 5 \\
\hline Empetrum nigrum & 1 & . & : & 1 & . & . & . & 1 & . & . & . & . & . & 3 \\
\hline Juncus compressus/gerardi & : & . & - & - & 24 & . & . & 21 & - & 1 & . & . & - & 46 \\
\hline Juncus sp. & . & . & 13 & 18 & & 3 & 61 & - & 7 & - & 1 & - & - & 103 \\
\hline Lychnis flos cuculi & - & . & - & 1 & : & 1 & - & - & 1 & : & . & - & - & 3 \\
\hline Phragmites australis & . & . & - & 1 & 1 & . & . & . & . & 1 & . & . & . & 3 \\
\hline Potentilla erecta & . & . & 10 & - & . & 1 & 3 & 3 & 1 & . & . & . & . & 18 \\
\hline Ranunculus flammula & . & . & 3 & 1 & 15 & 2 & $i$ & . & . & . & . & . & . & 22 \\
\hline Scirpus sylvaticus & . & . & 1 & 1 & 2 & 4 & 2 & . & . & . & . & . & . & 10 \\
\hline Solanum dulcamara & - & . & . & - & 2 & . & & - & - & . & . & . & & 2 \\
\hline Stellaria palustris & 1 & . & - & . & - & . & 1 & - & - & . & - & - & - & 2 \\
\hline \multirow{2}{*}{\multicolumn{15}{|c|}{$\begin{array}{l}\text { F. Plants of clifts } \\
\text { Calluna vulgaris }\end{array}$}} \\
\hline & . & - & - & - & . & $4 \mathrm{ku}$ & $3 k u+2$ & . & - & . & . & $1 \mathrm{ku}$ & - & 10 \\
\hline INDET. & $\cdot$ & - & - & - & - & . & - & 2 & - & . & - & $\cdot$ & $\cdot$ & 2 \\
\hline \multicolumn{15}{|l|}{ G. Other remains } \\
\hline Bryophyta/stems, leaves & . & $\cdot$ & 4 & 5 & 6 & 41 & . & 26 & $\cdot$ & . & . & . & - & 82 \\
\hline $\begin{array}{l}\text { Dicranum } \\
\text { Mnium }\end{array}$ & : & : & : & : & : & i & : & : & : & $\therefore$ & $\therefore$ & 1. & : & 1 \\
\hline Polythrichum & 3 & $i$ & . & : & : & 1 & . & . & . & . & : & : & : & 5 \\
\hline Sphagnum & & . & 2 & 1 & 3 & 1 & 2 & 10 & . & . & . & 1 & . & 20 \\
\hline Wood/uncharred & . & - & : & : & - & 11 & - & 10 & 1 & 9 & 8 & 12 & - & 51 \\
\hline Wood/charred & . & - & 7 & 4 & - & i & - & : & - & . & . & 2 & 3 & 16 \\
\hline Betula/bark & . & 4 & . & - & : & $!$ & : & 1 & $\therefore$ & : & : & - & - & 2 \\
\hline Linum/fibre? & - & 4 & - & . & : & is & - & $i t+$ & - & : & $\cdot$ & $\cdot$ & - & 4 \\
\hline Plant remains/mixed & $\cdot$ & • & $\cdot$ & +++ & • & +++ & +++ & +++ & +++ & $\cdot$ & +++ & $\cdot$ & $\cdot$ & $\cdot$ \\
\hline Pisces/scales & . & 6 . & . & - & - & 2 & 1 & . & . & . & . & . & . & 9 \\
\hline Lumbricus terrestris/cocoon & : & i & 13 & : & $\therefore$ & 10 & 3 & 14 & : & : & : & · & - & 40 \\
\hline $\begin{array}{l}\text { Bone } \\
\text { Insecta }\end{array}$ & : & $\stackrel{+}{.}$ & 10 & + & : & : & 10 & 10 & : & : & : & 2 & $\vdots$ & 32 \\
\hline $\begin{array}{l}\text { Insecta } \\
\text { Hairs }\end{array}$ & . & . & . & . & - & . & . & . & + & + & . & . & - & $\cdot$ \\
\hline SUM & 25 & 15 & 294 & 191 & 206 & 330 & 234 & 234 & 71 & 18 & 11 & 41 & 3 & 1673 \\
\hline
\end{tabular}

/h=charred, k=calyx, ku=flower, ko=capsule, kä/kär=tendril, n/nesneedle, +++=common 
61 I. Vuorela et al.
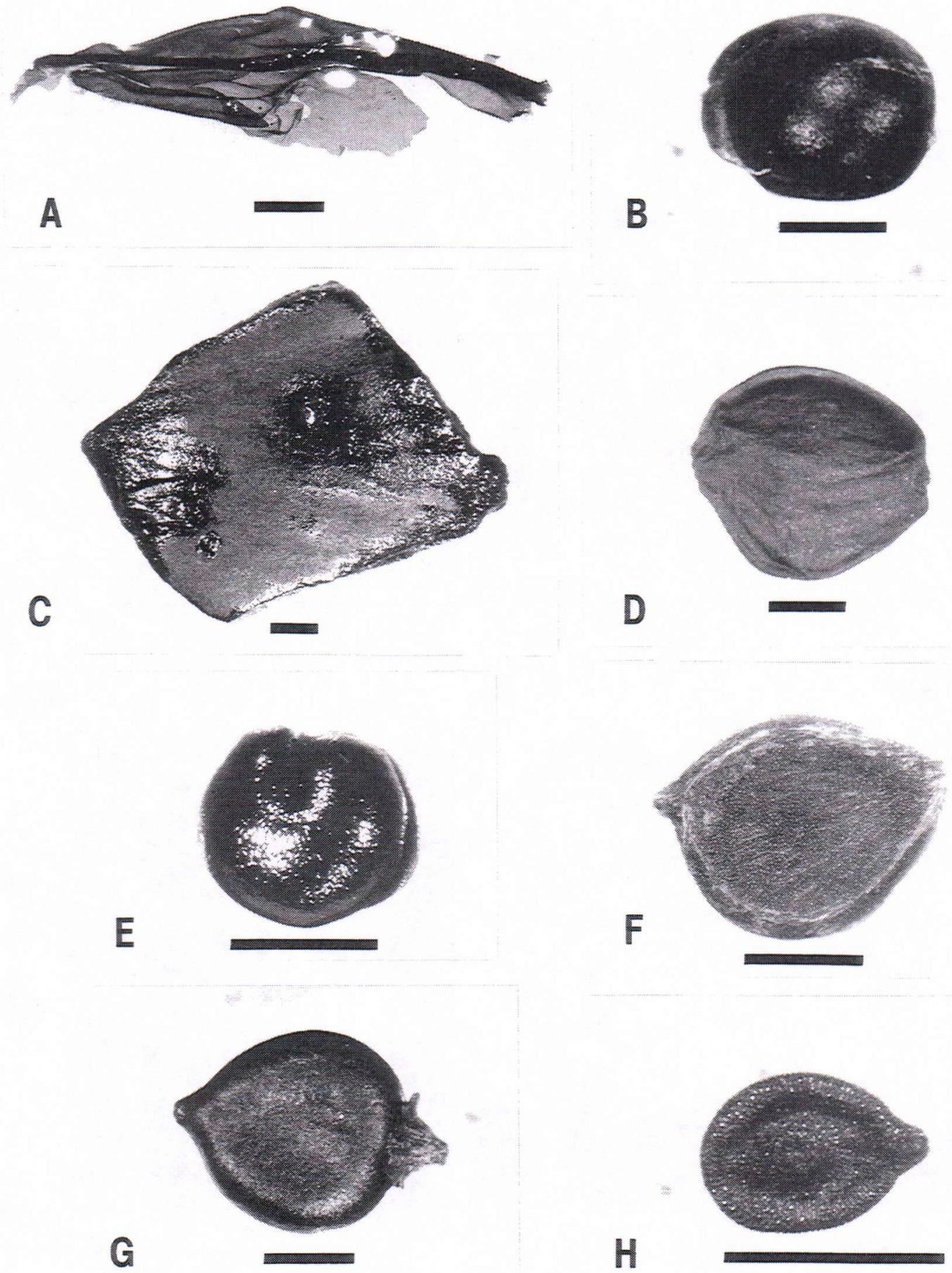

Figure 14. Plant remains found at the Rettig site: $A=$ Hordeum vulgare, uncharred grain, $B=$ Humulus lupulus, seed, $C=$ Corylus avellana, nut fragment, $D=$ Alnus sp., seed, $E=$ Chenopodium album, seed, $F=$ Ranunculus repens, seed, $G=$ Polygonum lapathifolium, seed, and $H=$ Dianthus deltoides, seed. Scale $=1 \mathrm{~mm}$. Photo: $T$. Lempiäinen. 
5.31-5.36-m level. Although this pollen type mainly reflects local cultivated fields, most clearly in the lower part of the diagram, it could indicate any activity related to crop growing in the intensily influenced anthropogenic upper layers (cf. Greig 1982, fig. 26). Among other cultivated plants, pollen of Fagopyrum esculentum was found at the $6.01-6.11-\mathrm{m}$ level, that of Humulus lupulus at the 4.81-5.01 m level and Pisum-type pollen grains at the 5.11-5.31 m level. At the Rettig site as at several other urban sites studied earlier, e.g. Turku Mätäjärvi (Vuorela 1989), Porvoo (Vuorela \& Hiekkanen 1991), Käkisalmi (Vuorela et al. 1992) and Helsinki (Vuorela \& Lempiäinen 1993, Vuorela 1994), pollen of Cichoriaceae is strongly represented, increasing in frequency at the rural/urban boundary. According to the present macrofossil data, this pollen type could represent Lapsana communis, Leontodon autumnalis, Sonchus asper or Sonchus arvensis (see Table 3). Other features in common with the investigations referred to are the relatively high pollen frequencies of Chenopodiaceae, Polygonum aviculare and Centaurea cyanus, the last in no relation to the Secale frequencies.

Among other settlement indicators, Urtica, Spergula arvensis, Rumex, Epilobium, Polygonum viviparum and P. lapathifolium (Fig. 14:G), Plantago major, Cirsium type and Lamiaceae were recorded, mainly in the upper part of the more or less naturally deposited lower half of the profile. Calystegia sepium most probably grew under the local shrubs.

It should be stressed that the above pollen types were almost equally present in all seven profiles investigated in the Rettig area (cf. Table 3).

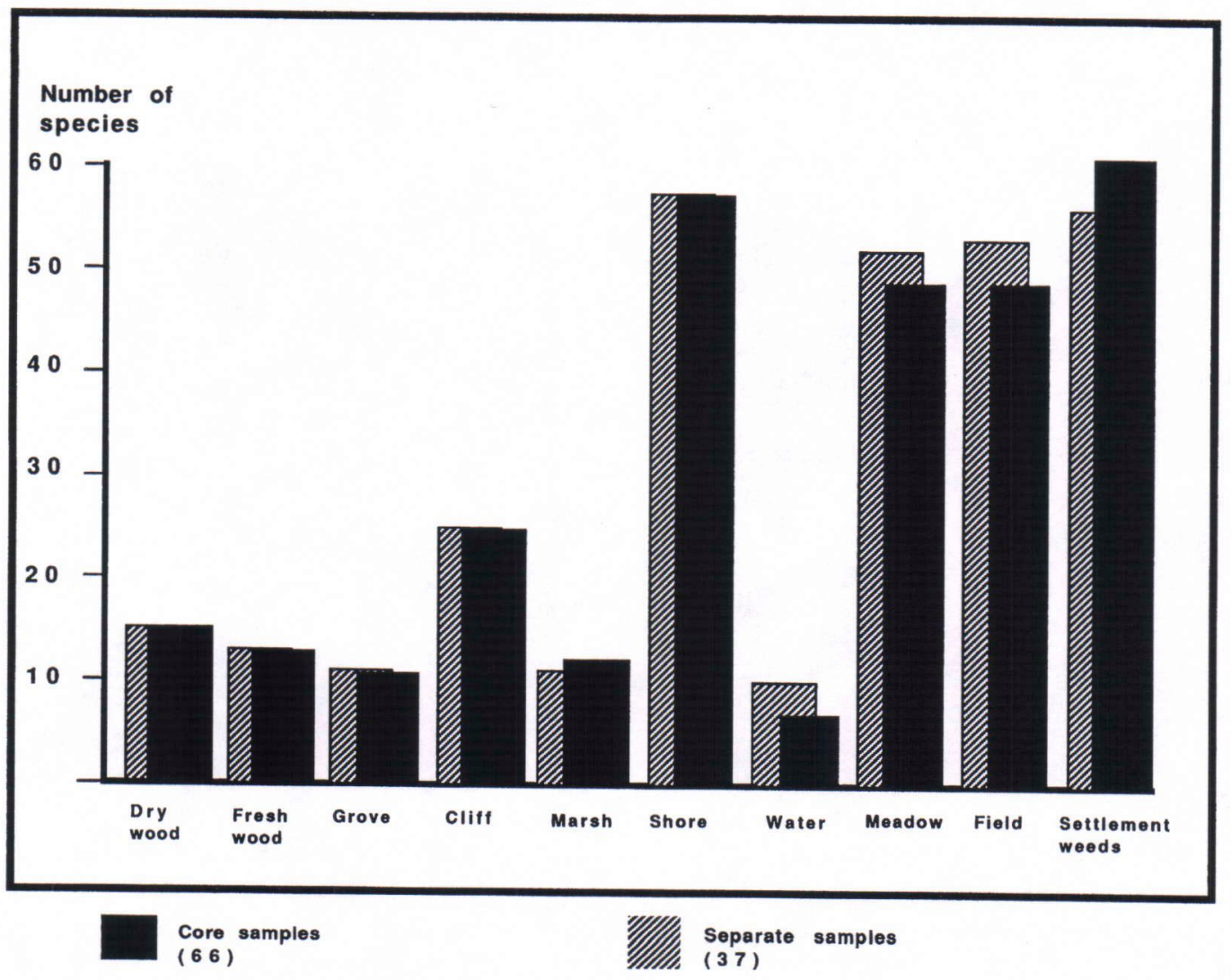

Figure 15. Distribution of inferred original habitats of the macrofossil flora found at the Rettig site in 1994-1995. 


\section{Macrofossils}

It is a rule rather than an exception that macrofossil plant remains stay where the plant once grew. That is why they provide such important evidence of the local vegetation of former settlement sites. They are particularly useful as remains of plants used by man, cereals and settlement weeds.

Macrofossil plant remains, especially soft plant cells, are very sensitive to corrosion, oxidation and decomposition. Not all plants used by man are represented in the lists because many of them, for instance, many cabbage species and spice plants, are harvested before they produce seeds. This is one of the reasons why we cannot get complete plant lists for the cores investigated. The interpretation of the natural macrofossil flora was based on the same factor as that of the pollen flora; the ecological requirements of the plants identified are largely known.

It is most important to identify cereals at species and subspecies levels. For that we need to compare them with macrofossils of old cereal species, forms and types.

The Rettig quarter was densely inhabited during the Middle Ages. It was part of the medieval centre of Turku (Ranta 1975), from where streets and main roads ran out into the countryside. In those days, people used to throw their rubbish into the streets or courtyards and refuse heaps were often formed. Plant remains accumulated in these heaps, in wells and ditches, on floors, around fireplaces, and also in manure. In the latter, the remains have been well preserved due to the mechanical shelter and favourable moisture conditions.

In this context only Core $\mathrm{C}$ will be presented (Fig. 2, Table 1) but the macrofossil results of all six profiles, together with the 33 samples analysed separately (Lempiäinen 1995a), are also referred to (Table 3). The total number of plant macrofossils found from the six profiles investigated by means of pollen and macrofossil analysis was 5563, 508 of them from Core B. Altogether 9986 macrofossils have been identified (Lempiäinen 1995b, Vuorela et al. 1996).

\section{Macrofossil results}

\section{Plants used by man}

Table 2 lists all macrofossil finds of cultivated/alien origin species in the Rettig area.

The total number of plant remains of cultivated/alien plants was 443 . It is c. $4.4 \%$ of the total amount of plant macroremains found in the Rettig area.

Table 2. Total number of plant macrofossils of cultivated/alien origin used by man found in the core samples plus the separate macrofossil samples from the Rettig excavation site. $*=$ charred

\begin{tabular}{lcc} 
Plant species & $\begin{array}{c}\text { Core samples } \\
(66)\end{array}$ & $\begin{array}{c}\text { Separate samples } \\
(37)\end{array}$ \\
\hline Avena sativa & & $8^{*}$ \\
Hordeum vulgare & $13^{*}$ & $134^{*}$ \\
Secale cereale & $1^{*}$ & $12^{*}$ \\
Triticum cf. aestivum & & $1^{*}$ \\
Triticum compactum & & $1^{*}$ \\
Cerealia & $1 *$ & $174^{*}$ \\
Cannabis sativa & 2 & 6 \\
Humulus lupulus & 61 & 20 \\
Linum usitatissimum & 1 & $5 *$ \\
Pisum sativum & & 1 \\
Ficus carica & 2 & 362 \\
Total sum & 81 &
\end{tabular}

\section{Cereals and other cultivated plants}

The most common cereal grain found in the Rettig material was Hordeum vulgare (Fig. 14:A). Barley was the main cereal in Finland in the Middle Ages (e.g. Soininen 1974, T. Vuorela 1975) and it was used both for food and for making beer. Other cereals still cultivated today, e.g. Secale cereale, Avena sativa and Triticum cf. aestivum were also found but less frequently than Hordeum. One grain of Triticum compactum was even found; this is an important find because $T$. compactum is a very primitive cereal with small grains and was probably not cultivated in Finland after the Middle Ages. A greater number of $T$. compactum grain finds dated to this age was found in the Old Market Place of 
Turku, nearby the Rettig site (Lempiäinen 1995a).

Eighty-one small nuts of Humulus lupulus (Fig. 14:B) were found. Hop is one of the most common macrofossil species dated to the Middle Ages in Turku (Lempiäinen 1985, 1988, 1995a, Aalto 1994). It was an important spice plant for beer and was cultivated by law in Finland at that time. Churchtithes also had to be paid in the form of hops (Suominen 1982).

Another spice used for beer was Myrica gale, and its seeds, too, were found in the Rettig area. As a native plant in the flora of Finland, it was collected from shores and marshes in southern Finland but is not known to have been cultivated. Leaves, seeds and also other parts of Myrica were used. Its toxicity in beer was not discovered until the 18th century. Drinking too much Myrica beer was a cause of death, and the use of the plant was prohibited (Vasari 1965, Behre 1984).

Important fibre plants in the Middle Ages were Cannabis sativa and Linum usitatissimum, both of which were found as macrofossils in the medieval layers of the Rettig site. Hemp was still an important cultivated fibre plant in Finland at the beginning of the 20th century (Linkola 1916). It was used for making coarse clothes and especially for sails, ropes and fishing tools which were important in Turku, Finland's main port (T. Vuorela 1975, Lempiäinen 1995a). Macrofossils of flax have been found in several medieval contexts in Turku (e.g. Lempiäinen 1985, 1995a,b, Valo 1993, Aalto 1994). No weeds of flax fields or flax capsules were found in the Rettig material. Flax was probably brought as a more or less ready processed fibre from Häme, central Finland or from Tallinn, Estonia, to be sold in Turku. Pisum sativum was mentioned in 1673 in the Catalogus plantarum of Elias Tillandz. Gadd (1751) also mentioned pea as a common cultivated plant in Satakunta, western Finland. Pea was widely cultivated in continental Europe in the Middle Ages (Behre 1983).

\section{Other useful plants}

Hyoscyamus niger was not very common in the Rettig material. The plant is not native in Finland but was known in the Viking Age (AD 800-1050; Lempiäinen 1991). The richest macrofossil finds are from Turku. It was an important medicinal plant, used especially for easing aches and rheumatic pain. It also played a role as a hallucinant in witch rituals. The plant was brought to the Nordic countries from southern Europe or western Asia by merchants, monks and soldiers. Henbane was first cultivated, but later spread as a weed. In the Middle Ages, henbane may also have been common as a herb in gardens in Turku.

Seeds of Chelidonium majus were also found. This plant was cultivated for its medicinal properties in Spain in the 14th century and may also have been brought to the Nordic countries by monks, merchants and travellers. The plant is mentioned in a letter written by King Gustaf Wasa of Sweden to the soldiers of the town of Viborg in 1556 (Pettersson 1965).

\section{Collected natural growing plants.}

Many remains of wild berries were found in the material analysed. Common were Fragaria vesca, Rubus idaeus, Vaccinium spp., Juniperus communis, Sorbus aucuparia, Rosa sp. and Corylus avellana (Fig. 14:C). They are native to southwestern Finland and common in the vicinity of Turku. Juniperus, for instance, is known to have been used as a medicine plant and as a disinfectant during plague epidemics, when its branches were burnt inside houses. It also served as a spice for beer (Erkamo 1944, Nikula \& Nikula 1987). A small piece of rope made of the cambium layer of Tilia cordata was also found. The fragments of Tilia nut shells were very common in all medieval layers of Rettig. Pieces of nuts were picked up from the soil at the time of excavation; whole nuts were rare. Nuts were used as a food or for making oil. They were also economically important in Finland (Suominen 1965).

Remains of other native plants that are thought to have been used by man (Tillandz 1673,1683 , Lönnrot 1838, 1860) were found in abundance, e.g. Arctostaphylos uva-ursi, Em- 

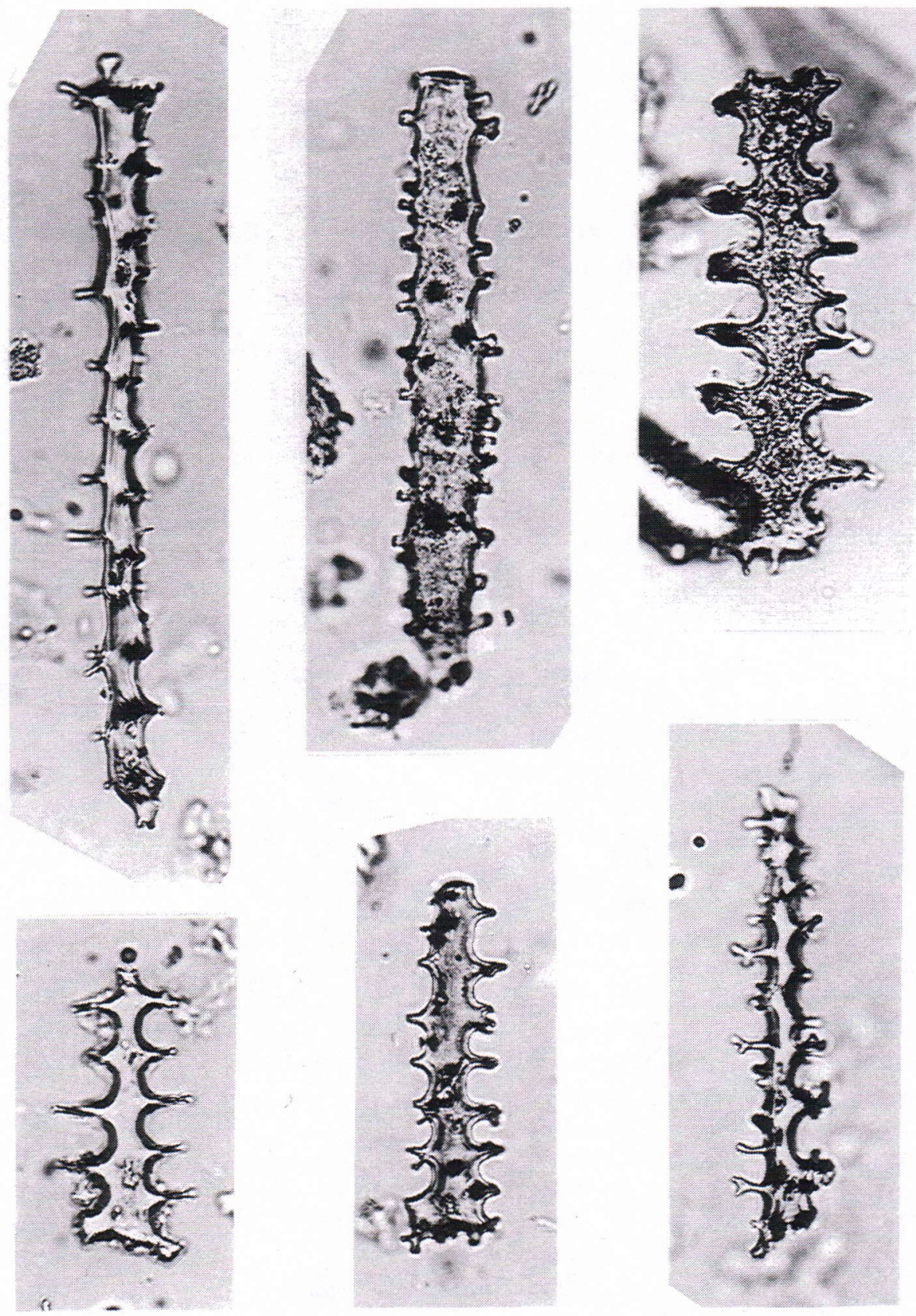

Figure 16. Phytoliths of Poacoid type (narrow elongated morphotypes) from the surface material of a grindstone found at the Rettig site. Photo: I. Vuorela. 
petrum nigrum, Urtica dioica, Calluna vulgaris, Galium sp., Viola sp., Stellaria media, Plantago major, Alchemilla sp., Veronica sp., Potentilla erecta, Ranunculus acris and Solanum dulcamara.

\section{Plants introduced by trade}

Seeds of fig (Ficus carica) are fairly common in the layers of medieval Turku (Lempiäinen 1995a,b). Fig may have been used as a medicinal plant (Erkamo 1944) but also as food by the wealthy inhabitants of Turku and the occupants of the castle (Aalto 1994). Another useful plant was Juglans regia; this was easy to transport by ship from the continent and to store dry like fig. However, very few finds of Juglans have been made in Finland. Macrofossil nuts of Juglans regia have been found in medieval Lund, southern Sweden (Hjelmqvist 1963).

\section{Natural vegetation}

Figure 15 shows the inferred original habitats and numbers of macrofossil plant species found at the Rettig site (Lempiäinen 1995b, Vuorela et al. 1996) classified according to Ellenberg (1979), Linkola (1916) and Hämet-Ahti et al. (1986). The most frequent plants derive from cultural habitats (settlement weeds) and shores or wetlands (together accounting for $20.4 \%$ of total). Equal proportions of plants, $16.4 \%$, grew in fields and meadows. The nearest pastures were located on the banks of the river Aura and the shores of Lake Mätäjärvi. They were habitats of plants such as Carex sp., Eleocharis palustris, Juncus sp., Phragmites australis, Filipendula ulmaria, Ranunculus flammula, Scirpus sylvaticus and Solanum dulcamara, all of which were found in the macrofossil material. A representative of sea-shore plants was Aster tripolium. The remains of plant species of woods, marshes, groves and waters were all equally represented. The following plants come from moist or wet habitats: Lychnis flos-cuculi, Alisma plantago-aquatica and Caltha palustris, Callitriche sp., Elatine sp., Potamogeton sp., Sparganum sp., and Batrachium. Plants growing on rocks, cliffs and dry hillsides were fairly common as the rock of
Vartiovuori is in the immediate vicinity of the site.

\section{COMPARISON OF MACROFOSSIL AND POLLEN DATA}

In Table 3 the macrofossil and pollen taxa identified from all the Rettig samples are placed side by side. Most of the anthropogenic macrofossil species can be identified at species level, whilst the pollen types are often identified at family level. Of the 72 pollen taxa identified, 57 have a corresponding taxon among the macrofossils. Mainly due to the well represented large families such as Caryophyllaceae, 124 plant macrofossil taxa have corresponding pollen taxa. Anthropogenic plants reflecting the local vegetation of the site are best represented in the mutual pollen and macrofossil data. Most of the macrofossil plant species found belong to the families Caryophyllaceae, Ranunculaceae, Rosaceae, Lamiaceae, Asteraceae, Cichoriaceae, Cyperaceae and Poaceae.

Table 3. Pollen and plant macrofossil taxa identified from the Rettig material in 1994-1995.

\begin{tabular}{ll}
\hline Pollen taxa & Macrofossil taxa \\
\hline Cerealia & Avena sativa \\
& Hordeum vulgare \\
& Triticum aestivum \\
& Triticum compactum \\
Secale cereale & Secale cereale \\
\hline Polypodiaceae & Dryopteris thelypteris \\
Picea & Picea abies \\
Pinus & Pinus sylvestris \\
Juniperus & Juniperus communis \\
Ranunculus acris & Ranunculus acris \\
Ranunculaceae & Batrachium sp. \\
& Ranunculus flammula \\
& Ranunculus repens \\
Caltha & Ranunculus sceleratus \\
Thalictrum & Caltha palustris \\
Cannabis sativa & Thalictrum flavum \\
Humulus lupulus & Cannabis sativa \\
Urtica & Humulus lupulus \\
Quercus & Urtica dioica \\
Alnus & Urtica urens \\
Betula & Quercus robur \\
Corylus & Alnus sp. \\
Caryophyllaceae & Betula sp. \\
& Corylus avellana \\
& Agrostemma githago \\
&
\end{tabular}


Table 3. Continuing.

Polygonum aviculare Polygonum aviculare
Polygonum persicaria type Polygonum lapathifolium
\[ \begin{array}{l}\text { Polygonum persicaria } \\ \text { Polygonum minus }\end{array} \]

Fallopia convolvulus

Rumex

Hypericum

Brassicaceae

Salix

Calluna vulgaris

Ericaceae

Tilia

Rosaceae

Potentilla

Filipendula

Trifolium

Pisum type

Vicia type

Fabaceae

Apiaceae

Rubiaceae

Valeriana

Lamiaceae

Plantago major/media Asteraceae

Antennaria

Artemisia
Centaurea cyanus

Cirsium

Cerastium sp.

Cichoriaceae

Dianthus deltoides

Lychnis flos-cuculi

Sagina sp.

Scleranthus annuus

Silene nutans

Spergularia sp.

Stellaria graminea

Stellaria media

Stellaria palustris

Spergula arvensis

Atriplex patula

Chenopodium album

Chenopodium suecicum

Chenopodium glaucum/rubrum

Chenopodium hybridum

Fallopia convolvulus

Fallopia dumetorum

Rumex acetosa

Rumex acetosella

Rumex crispus

Hypericum maculatum

Brassica/Raphanus

Camelina sp.

Capsella bursa-pastoris

Rorippa palustris

Thlaspi arvense

Salix sp.

Calluna vulgaris

Arctostaphylos uva-ursi

Empetrum nigrum

Vaccinium myrtillus

Vaccinium sp.

Tilia cordata

Alchemilla sp.

Rosa sp.

Potentilla anserina

Potentilla erecta

Fragaria vesca

Comarum palustris

Filipendula ulmaria

Trifolium repens

Pisum sativum

Vicia sp.

Lathyrus pratensis

Pimpinella saxifraga

Galium mollugo

Galium sp.

Galium aparine

Valeriana officinalis

Galeopsis speciosa

Lamium purpureum

Lycopus europaeus

Prunella vulgaris

Plantago major

Leucanthemum vulgare

Chrysanthemum segetum

Gnaphalium sylvaticum

Solidago virgaurea

Aster tripolium

Antennaria dioica

Artemisia vulgaris

Alisma

Potamogeton

Sparganium

Cyperaceae

Poaceae
Festuca sp.

Phragmites australis

Poa annua

Poa pratensis/trivialis

Puccinellia sp.

Poaceae

\begin{tabular}{ll}
\hline Sphagnum & Sphagnum sp. \\
\hline No pollen & Ficus carica \\
& Juglands regia \\
& Linum usitatissimum \\
& Rubus idaeus \\
Sorbus aucuparia \\
Juncus articulatus \\
Juncus bufonius \\
Juncus compressus/gerardii \\
Juncus sp. \\
Luzula campestris \\
Luzula pilosa \\
Veronica officinalis \\
Chelidonium majus \\
Hyascyamus niger
\end{tabular}

\section{PHYTOLITHS}

Even though the samples for phytolith analysis were all taken from one object - a grindstone the plant stones represent two different collections. In the samples taken from the upper surface only a few phytoliths were found, the majority of them narrow elongate morphotypes of Poacoid type (Fig. 16; cf. Rovner 1971). The uniform collection of morphotypes suggests certain plant species but no phytoliths from cereals were identified. Most samples from the base of the stone showed relatively high frequencies of phytoliths of several morphotypes, probably originating from the former local vegetation. Similar elongate morphotypes have been found among Elymus 
repens and Dactylis glomerata (cf. Tingvall 1995).

\section{CONCLUDING REMARKS}

The cultural layer and the underlying clay deposits beneath act as an archive of major historical value. The diatom flora reflect the development of the coastal landscape from open sea through archipelago to the mainland of today. Pollen and plant macrofossils record the changes in vegetation during the transformation from a natural landscape to a cultural landscape and finally to an urban settlement. They also provide insight into the plants used for food, medicine and fibres in the medieval town of Turku.

The phytoliths found and described from the surface of a grindstone at the Rettig site add to the fossil data currently available on pollen and plant macrofossils. 


\section{LITERATURE}

Aalto, M. 1994. Turun Linnan esilinnan kasvillisuus. In: Knut Drake (ed.) Turun Maakuntamuseon (TMM) Raportteja 16, 21-38.

Alhonen, P. 1979. The Quaternary history of the Baltic, Finland. In: Gudelis, V. \& Königsson, L.-K. (eds) The Quaternary history of the Baltic. Acta Universitas Upsaliensis Symposia Universitatis Uppsaliensis. Annum Quingentesimum Celebrantis $1,101-113$.

Battarbee, R. 1986. Diatom analysis. In: Berglund, B.E. (ed.) Handbook of Holocene Palaeoecology and Palaeohydrology. John Wiley \& Sons Ltd., 527-570.

Behre, K.-E. 1976. Die Pflanzenreste aus der frühgeschichtlichen Wurt Elisenhof. Die frühgeschichtliche Marschensiedlung beim Elisenhof in Eiderstedt 2. Bern. Lang. 144 p.

Behre, K.-E. 1983. Ernährung und Umwelt der wikingerzeitlichen Siedlung Haithabu. Die Ausgrabungen in Haithabu. Neumünster. 219 p.

Behre, K.E., 1984. Zur Geschichte der Bierwürzen nach Fruchtfunden und schriftlichen Quellen. In: W.van Zeist \& W.A.Casparie (eds) Plants and ancient man, 115-122.

Behre, K.-E. 1991. Umwelt und Ernährung der frühmittelalterlichen Wurt Niens/Butjadingen nach den Ergebnissen der botanischen Untersuchungen. Probleme der Küstenforschung in südlichen Nordseegebiet. Band 18, 141-168 + Tafel I-V.

Beijerink, W. 1947. Zadenatlas der Nederlandsche Flora. Wageningen. 316 p.

Clapman, A.J. \& Scaife, R.G. 1988. A pollen and plant macrofossil investigation of Oakbank Crannog, Loch Tay, Scotland. In: Murphy, P. \& French, Ch. (eds) The exploitation of Wetlands. BAR British Series 186, 293-325.

Ellenberg, H. 1979. Zeigerwerte der Gefässpflanzen Mitteleuropas. 2. Aufl.- Scripta Geobotanica 9. Göttingen. 97 p.

Erdtman, G., Berglund, B.E. \& Praglowski, J. 1961. An introduction to a Scandinavian pollen flora. Almqvist \& Wiksell, Stockholm. 92 p. + 74 Plates.

Erkamo, V., 1944: Vanhin Suomesta tunnettu lääkeopillinen kirjoitus. (Deutsch Referat: Die Älteste aus Finnland bekannte medizinische Schrift). Duodekim 60, 210222.

Eronen, M. 1974. The history of the Litorina Sea and associated Holocene events. Commentationes Physico-Mathematicae 44, (4). 195 p.
Faegri, K. \& Iversen, J. 1989. Textbook of Pollen Analysis. K. Faegri, P.E. Kaland \& K. Krzywinski eds. John Wiley \& Sons. New York. 328 p.

Florin, M.-B. 1946. Clypeusfloran i postglaciala fornsjölagerföljder i östra Mellansverige. Geologiska Föreningens i Stockholm Förhandlingar 68, $429-438$.

Gadd, P.A. 1751. Försök till en oekonomisk Beskrifning öfwer Satakunda Häraders Norra Del. Stockholm, 148 p.

Glückert, G. 1976. Post-glacial shore-level displacement of the Baltic in SW Finland. Annales Academiae Scientiarum Fennicae A III, 811. 92 p.

Glückert, G. 1977. Itämeren rannansiirtymisestä Turussa ja sen lähiympäristössä. Turun yliopiston maaperägeologian osaston julkaisuja $21.36 \mathrm{p}$.

Greig, J. 1982. The interpretation of pollen spectra from urban archaeological deposits. In: Hall. A.R. \& Kenward, H.K. (eds) Environmental archaeology in the urban context. Council of Brittish Archaeology (CBA) Research Report Nr. 43, 47-65.

Hämet-Ahti, L., Suominen, J., Ulvinen, T., Uotila, P. \& Vuokko, S. 1986. Retkeilykasvio. Suomen Luonnonsuojelun Tuki. Helsinki. 598 p.

Hjelmqvist, H. 1963. Frön och frukter från det äldsta Lund. Archaeologica Lundensia 2, 233276.

Hultén, E. 1971. Atlas of the distribution of vascular plants in northwestern Europe. 2nd Ed. AB Kartografiska institutet, Stockholm. 531 p.

Ignatius, H. and Tynni, R. 1974. Itämeren vaiheet ja piilevätutkimus. Turun yliopiston maaperägeologian osaston julkaisuja 36. $26 \mathrm{p}$.

Ignatius, H., Korpela, K. \& Kujansuu R. 1980. The deglaciation of Finland after 10,000 B.P. Boreas 9, 217-228.

Körber-Grohne, E. 1967. Geobotanische Untersuchungen auf der Feddersen-Wierde, Bd. 1. Wiesbaden. 357 p.

Krammer, K. \& Lange-Bertalot, H. 1986-1991. Bacillariophyceae. Teil 1-4. Süsswasserflora von Mitteleuropa $2 / 1,876$ p. (1: Naviculaceae, 1986), 2/2, 596 p. (2: Bacillariaceae, Epithemiaceae, Surirellaceae, 1988), 2/3, 576 p. (3: Centrales, Fragilariaceae, Eunotiaceae, 1991a), 2/4, 437 p. (4: Achnantheaceae \& Kritische Ergänzungen zu Navicula (Lineolate) und Gomphonema, 1991b).

Lempiäinen, T. 1985. Plant remains from the ancient Lake Mätäjärvi. ISKOS 5, 258-271.

Lempiäinen, T. 1988. Pflanzliche Makroreste von dem Innenhof des Qwenselschen Anwesens in Turku, SW Finnland, vom 17.-19.-Jh. Annales Botanici Fennici 25, 47-54. 
Lempiäinen, T. 1989. Turun muinaisen Mätäjärven kasvijäänteet. Turun Maakuntamuseon (TMM) Raportteja 10, 193-205.

Lempiäinen, T. 1991. Past occurrence of Hyoscyamus niger L. (Solanaceae) in Finland according to the macrofossil finds. Annales Botanici Fennici 28, 261-272.

Lempiäinen, T. 1995a. Macrofossil finds from the Medieval Turku, SW Finland. Res archaeobotanicae 1995, 149-164.

Lempiäinen, T. 1995b. Rettigin tontin makrofossiilitutkimukset vv. 1994-1995. Aboa Vetus-tutkimushanke. Tutkimusraportti. Turun yliopisto, Biologian laitos. $41 \mathrm{p}$.

Lempiäinen, T., Niemi, R., Räsänen, M., Salonen, V.-P., Terho, A., Vuorela, I. \& Vuorisalo, T. 1986. Mätäjärvi-projektin luonnontieteelliset tutkimustulokset kertovat ympäristön muutoksista Turun seudulla. Luonnon Tutkija 90(3), 120-129.

Linkola, K. 1916. Studien über den Einfluss der Kultur auf die Flora in den Gegenden nördlich vom Ladogasee I. Allgemeiner Teil. Acta Societas Fauna Flora Fennica 45(1), 1485.

Lönnrot, E. 1838. Suomalaisen talonpojan kotilääkäri. Tampere, $153 \mathrm{p}$.

Lönnrot, E. 1860. Flora Fennica. Suomen Kasvisto. Helsinki. Suomalaisen Kirjallisuuden Seura. 376 p.

Miller, U. \& Robertsson, A.-M. 1979. Biostratigraphical investigations in the Anundsjö region, Angermanland, Northern Sweden. Early Norrland 12, 1-76.

Mölder, K. \& Tynni, R. 1967-1973. Über Finnlands rezente und subfossile Diatomeen I-VII. Bulletin of the Geological Society of Finland 39: 199-217; 40: 151-170; 41: 235-251; 42: 129-144; 43: 203220; 44: 141-149; 45: 159-179.

Moore, P.D., Webb, J.A. \& Collinson, M.E. 1991. Pollen analysis. 2nd edition. Blackwell Scientific Publications. Oxford. 216 p.

Niemi, R. 1989. Mätäjärven punkkijäännökset (Sw. Kvalsterrelikterna från Mätäjärvi). Turun Mätäjärvi (Mätäjärvi i Åbo). Turun maakuntamuseo/Åbo landskapsmuseum, 215-219 (220-221).

Nikula, O. \& Nikula, S. 1987. Turun kaupungin historia 15211600 . III. $776 \mathrm{p}$.

Pettersson, B. 1965. Humala (Humulus lupulus L.). In: Jalas, J. (ed.) Suuri Kasvikirja II. Helsinki. 851 p.

Powers, A.H., Padmore, J. \& Gilbertson, D.D. 1988. Studies of Late Prehistoric and Modern Opal Phytoliths from Coastal Sand Dunes and Machair in North West Britain. Journal of Archaeological Science 16(1), 27-45.
Ranta, R. 1975. Turun kaupungin historia 16001721. I. Turku. 529 p.

Round, F.E., Crawford, R.M. \& Mann, D.G. 1990. The diatoms - Biology and morphology of the genera. Cambridge University Press, Cambridge. 747 p.

Rovner, I. 1971. Potential of opal phytoliths for use in palaeoecological reconstruction. Quaternary Research 1(3), 343-359.

Salonen, V.-P., Räsänen, M. \& Terho, A. 1989. Mätäjärven paleolimnologinen kehitys (Sw. Mätäjärvis paleolimnologiska evolution), Turun Mätäjärvi (Mätäjärvi i Åbo). Turun maakuntamuseo/Åbo landskapsmuseum, 169-173 (174-186).

Soininen, A.M. 1974. Vanha maataloutemme. Maatalous ja maatalousväestö Suomessa perinnäisen maatalouden loppukaudella 1720luvulta 1870luvulle. Journal of the Scientific Agricultural Society of Finland 46 (Suppl.). 459 p.

Stockmarr, J. 1971. Tablets with spores in absolute pollen analysis, Pollen et Spores 4, 615-621.

Suominen, J. 1965. Pähkinäpensas (Corylus avellana L.). In: Jalas, J. (ed.) Suuri Kasvikirja. Helsinki. 851 p.

Suominen, J. 1982. Suomen luonnonvarainen humala (Humulus lupulus L.). Alkon keskuslaboratorio. Seloste 8174.

Tillandz, E. 1673. Catalogus plantarum tam in excultis, quam in cultis locis prope Aboam superiore aestate nasci observatarum. Aboae.

Tillandz, E. 1683. Catalogus plantarum quae prope Aboam tam in excultis, quam in cultis locis hucuscue in ventae sunt. Aboae.

Tingvall, C. 1995. Studier av fytoliter hos några recenta sädesslag och andra gräs. (Phytolith studies of selected cereals and other grasses). Bot. Inst. Göteborgs Univ. 17 p. Unpublished.

Tynni, R. 1975-1980. Über Finnlands rezente und subfossile Diatomeen, VIII-XI. Geological Survey of Finland, Bulletin 247: 55 p.; 284: 37 p.; 296: 55 p.; 312: 93 p.

Valo, O. 1993. Kasveja 1600-luvun Turusta. Paleoetnobotaaninen tutkimus Julinin tontilta. Pro Gradututk. Turun yliopisto, Biologian laitos. $43 \mathrm{~s}$.

Vasari, Y. 1965. Suomyrtti (Myrica gale L.). In: Jalas, J. (ed.) Suuri Kasvikirja II. Helsinki, 851 p.

Vuorela, I. 1985. The polla data of Mätäjärvi, Turku, SW Finland. ISKOS 5. Helsinki: Suomen Muinaismuistoyhdistys, 247-257.

Vuorela, I. 1989. Utvecklingen omkring Mätäjärvi i ljuset av pollenanalys. In: Turun Mätäjärvi. Mätäjärvi i Åbo, Turun maakuntamuseo/Åbo landskapsmuseum. Raportteja 10. Turku: Turun Maakuntamuseo, 187-193. 
Vuorela, I. 1991. Airborne charcoal particles as components of urban cultural layers. Pact 33 (II.8), 187-192.

Vuorela, I. 1994. Palynological investigations in the old town of Helsinki. In: Korhola, A. \& Lunkka, J.P. (eds) The Second Meeting of Finnish Palaeobotanists: Late Quaternary Vegetation and Climate Changes, Tvärminne, 26.-28.4.1993. Bulletin of the Geological Society of Finland 66(2), 125-128.

Vuorela, I. \& Hiekkanen, M. 1991. The urban milieu of the late- and postmedieval town of Porvoo, southern Finland investigated by means of pollen analysis. Annales Botanici Fennici 28, 95-106.

Vuorela, I., Saksa, A., Lempiäinen, T. \& Saarnisto, M. 1992. Pollen and macrofossil data on deposits in the wooden fortress of Käkisalmi dated to about
AD 1200-1700. Annales Botanici Fennici 29, 187-196.

Vuorela, I. \& Lempiäinen, T. 1993. Palynological and palaeobotanical investigations in the area of the post-medieval Helsinki Old Town. Vegetation History and Archaeobotany 2 (2), 101-123.

Vuorela, I., Grönlund, T. \& Lempiäinen, T. 1996. Paleoekologisia tutkimuksia Rettigin tontilta Turusta. Geological Survey of Finland, Unpublished archieval Report P 34.4.115. 143 p.

Vuorela, T. 1975. Suomalainen kansankulttuuri. Porvoo-Helsinki-Juva. 776 p.

Vuorisalo, T. \& Virtanen, T. 1989. Mätäjärven luulöydöt (Sw. Benfynden från Mätäjärvi). Turun Mätäjärvi, Mätäjärvi i Åbo, Turun maakuntamuseo/Åbo landskapsmuseum, 222-226 (227-229). 